\title{
Pengembangan Mobile Multimedia Learning Mata Pelajaran Pendidikan Jasmani Olahraga Dan Kesehatan Materi Kombinasi Gerak Berjalan Berlari Dan Meloncat Untuk Siswa Kelas III Di Sekolah Dasar Insan Mulya Driyorejo Kabupten Gresik
}

\author{
Muhammad Dewantoro ${ }^{1}$, Andi Mariono ${ }^{2}$, Fajar Arianto ${ }^{3}$ \\ Teknologi Pendidikan Pascasarjana Universitas Negeri Surabaya \\ Jl. Unesa IDB, Lidah Wetan, Kec. Lakarsantri, Surabaya \\ Email: ${ }^{1}$ muhammadkartika.19003@mhs.unesa.ac.id, ${ }^{2}$ andimariono@unesa.ac.id \\ fajararianto@unesa.ac.id
}

\begin{abstract}
Abstrak
Penelitian ini merupakan Penelitian dan Pengembangan yang bertujuan untuk menghasilkan produk media pembelajaran pada mata pelajaran pendidikan jasmani olahraga dan kesehatan kelas III Sekolah Dasar Insan Mulya Driyorejo Kabupaten Gresik. Masalah dalam penelitian ini dirumuskan sebagai berikut: (1) Bagaimana proses pengembangan mobile multimedia learning mata pelajaran pendidikan jasmani olahraga dan kesehatan materi kombinasi berjalan berlari dan meloncat untuk siswa kelas III di di Sekolah Dasar Insan Mulya Driyorejo Kabupaten Gresik. (2) Apakah media mobile multimedia learning mata pelajaran pendidikan jasmani olahraga dan kesehatan materi kombinasi berjalan berlari dan meloncat layak digunakan untuk siswa kelas III di Sekolah Dasar Insan Mulya Driyorejo. Penelitian dan Pengembangan ini mengacu pada langkah-langkah model pengengembangan Lee \& Owens, yang meliputi: (1) Assessment/analysis (penilaian/analisis), (2) Design (desain), (3) Development (Pengembangan Produk), (4) Implementation (implementasi), (5) Evluation (evaluasi). Sampel penelitian dan pengembangan ini terdiri dari dua ahli materi dan dua ahli media. Analisis pada penelitian ini menggunakan analisis deskriptif kuantitatif. Data dalam penelitian ini diambil melalui wawancara, observasi, dan kuesioner. Berdasarkan hasil pengolahan data diperoleh hasil uji validitas dari ahli materi sebesar 93,1\% dan hasil validitas ahli media dari segi edukatif sebesar $100 \%$, dari segi kualitas teknis sebesar 95,31\% dan uji validitas ahli media secara keseluruhan sebesar 96,25\%, sehingga dapat disimpulkan bahwa multimedia pembelajaran sangat layak untuk digunakan.
\end{abstract}

Kata Kunci : Multimedia, Mobile Multimedia, Pendidikan Jasmani Olahraga Dan Kesehatan, Gerak Berjalan Berlari Dan Meloncat

\section{PENDAHULUAN}

Proses pembelajaran adalah suatu kegiatan yang di dalamnya teradapat interaksi antara pebelajar dan pembelajar dimana terjadi komunikasi timbal balik dan berlangsung dalam situasi edukatif untuk mencapai tujuan pembelajaran dimana hal tersebut dijelaskan dalam Sistem Pendidikan Nasional yang terdapat pada UU No. 20 Tahun 2003. Saat ini telah memasuki pada Pendidikan sekarang ini berada dalam Abad 21, tertanda dengan adanya revolusi industry 4.0 yakni globalisasi dan keterbukaan. Sekarang teknologi mengalami perkembangan sangat pesat. Peran teknologi sangat penting membantu manusia di bidang apapun dalam mempermudah pekerjaan.
Teknologi yang berkembang saat ini telah mencakup bermacam sektor. Teknologi pada komunikasi berupa alat elektronik dan perangkat lunak telah mempengaruhi sektor kehidupan manusia termasuk dalam sektor pendidikan.

Dewasa ini hampir semua kegiatan pendidikan dan pembelajaran memanfaatkan teknologi sebagai inovasi dalam mengatasi masalah yang muncul dalam dunia pendidikan. Penemuan dalam ilmu pengetahuan tidak hanya mengatasi masalah saja akan tetapi juga membuat lingkungan pendidikan maju sehingga membuntang bermacam pemutakhiran. Salah satunya di pendidikan yakni kemunculan hal baru yang 
memanfaatkan raingan computer dan interneet dalam proses pembelajaran disebut e-learning atau pembelajaran elektronik. Munir (2009: 208) menjelaskan bahwa E-learning pembelajaran pada pengejawantahannya menggunakan media ataupun jasa bantuan peranti elektronik. Seperti audio, video, dan peranti komputer maupun penyatuan ketiganya. Dari hal itu, e learning dalam pembelajaran jarak jauh saat ini telah diterapkan.

Menurut Dogmen dalam Munir (2009), pembelajaran jarak jauh adalah ditekankannya pembelajaran yang secara mandiri (self study). Kekhasan belajar secara jarak jauh materinya disampaikan dengan media, tanpa kontak langsung antara pembelajar dan pebelajar, dan diatur organisasi. Pembelajaran yang digunakan secara jarak jauh di sekolah untuk guru dan di tempat siswa belajar dibutuhkan perangkat elektronika yang dapat dijadikan sebagai alat kegiatan pembelajaran jauh, seperti computer maupun smartphone. Kemudian dikembangkan media pembelajaran yang dirancang dan didesain khusus untuk dilaksanakannya pembelajaran secara jarak jauh, salah satu media yang dapat digunakan untuk pembelajaran jarak jauh adalah Pembelajaran jarak jauh dengan menggunakan smartphone yang sering kita jumpai dengan istilah mobile multimedia learnining.

Meningkatnya prevalensi teknologi mobile terbukti dalam statika antara 8 sampai 18 tahun antara 2004 dan 2009, kepemilikan telepon seluler meningkat dari 39 persen menjadi 66 persen (Rideout et al., 2010 in Guglielmo Trentin 2013). Di tahun 2018 ke atas diperkirakan oleh lembaga riset digital marketing bahwa lebih dari seratus juta yang aktif memakai smartphone. Perkiraan tersebut diutarakan karena data pada tahun 2015 telah mencapai $25 \%$ dari jumlah semua penduduk Indonesia kurang lebih 65 juta yang menggunakan. (Rahmayani Indah 2015). Sebagai paradigma pembelajaran secara jarak jauh masih belum diaplikasikan sebagai cara berfikir, hanya konsep dan perangkat teknis saja. Padalah pembelajaran yang semacam itu tidaklah sebagai metode memberikan tugas setiap hari yang banyak sebagai beban siswa, dan menjadikan belajar menggunakan aplikasi mengubah belajar tatap muka.

Pengetahuan yang dijadikan sebagai sumber bagi siswa dalam mengaksesnya sebanyak mungkin menjadikan mereka sangat kratif, berkarya, wawasan yang diasah, dan siswa seharusnya terdorong untuk itu. Pada akhirnya terbentuk pebelajar sepanjang hayat. Gagne dalam Muhammad Rohman (2013: 156), siswa bisa terangsang belajar, salah satunya oleh media pembelajaran, hal ini di lingkungan siswa digunakan sebagai komponen sumber dalam belajar. Dalam tercapainya tujuan pembelajaran dilakukan secara jarak jauh dibutuhkan media pembalajaran dengan materi pembelajaran yang dirancang khusus dan sesuai dengan kebutuhan kegiatan pembelajaran tersebut. Dengan diciptakannya media pembelajaran seperti itu, maka penyampaian materi ajar atau kegiatan pembelajaran yang dilakukan saat jarak jauh menjadi lebih efektif dan efisien.

Dalam tercapainya tujuan pembelajaran dilakukan secara jarak jauh dibutuhkan media pembalajaran dengan materi pembelajaran yang dirancang khusus dan sesuai dengan kebutuhan kegiatan pembelajaran tersebut. Dengan diciptakannya media pembelajaran seperti itu, maka penyampaian materi ajar atau kegiatan pembelajaran yang dilakukan saat jarak jauh menjadi lebih efisien.

Wiradiharja (2017) menjelaskan bahwa Pendidikan Jasmani Olahraga dan Kesehatan adalah suatu proses pembelajaran melalui aktivitas gerak yang didesain untuk meningkatkan kebugaran jasmani, mengembangkan keterampilan gerak, pengetahuan dan perilaku hidup sehat dan aktif, sikap sportif, dan kecerdasan emosi. Perencanaan yang sistematis juga direncanakan untuk mewujudkan tujuan pendidikan nasional tentang aspek hidup dengan pola yang sehat serta lingkungan bersih melangkaui aktivitas jasmani, olahraga dan kesehatan.

Di pembelajaran jarak jauh aktivitas olahraga tetap dilakukan di rumah oleh siswa. Pada kelas 3 Sekolah Dasar Siswa perlu dibimbing oleh orang tua dalam melakukan aktivitas olarhaga tersebut. Dengan tidak 
adanya guru secara langsung memungkinkan melakuan aktivitas gerakan dengan kurang benar atau kurang sesuai, sehingga dalam pembelajaran jarak jauh seperti ini aspek teori lebih diperkuat sehingga siswa mampu melakukan gerakan olahraga secara mandiri di rumah dengan benar dan sesuai walau tanpa ada gurunya secara langsung. Pembelajaran jarak jauh yang didesain untuk pembelajaran olahraga harus dirancang khusus untuk memperkuat aspek teori dan mudah dipahami oleh siswa kelas 3 Sekolah Dasar.

Sementara itu yang terjadi di SD Insan Mulya Driyorejo kurang sesuai dengan kondisi ideal seperti dijelaskan di atas. Di SD Insan Mulya Driyorejo, telah melakukan pembelajaran jarak jauh akan tetapi, penggunaan media ponsel pintar untuk pembelajaran, khususnya mata pelajaran PJOK (Pendidikan Jasmani dan Olahraga) materi Aktivitas bermain, kombinasi berjalan, berlari, dan melompat belum dilakukan secara maksimal. Di sekolahan tersebut belum memiliki media atau bahan ajar praktis, terformat, dan komprehensif, yang dirancang khusus untuk Mata pelajaran PJOK materi Aktivitas bermain kombinasi berjalan, berlari dan melompat yang menyebabkan pembelajaran jarak jauh secara mandiri kurang maksimal. Maka dari itu pembelajaran pada mata pelajaran PJOK kelas III SD Insan Mulya Driyorejo membutuhkan media pembelajaran yang dirancang khusus untuk mata pelajaran PJOK materi aktivitas bermain kombinasi berjalan, berlari, dan melompat yang mampu memicu siswa mudah paham materi secara mandiri.

\section{TINJAUAN TEORI Pengembangan}

Adapun pengertian pengembangan menurut Januzewski and Molenda (2008: 1). mengungkapkan bahwa pengembangan adalah aktivitas menghasilkan rang atau produk untuk bisa dipakai memeacahkan problem aktual. Tatkala hal ini, tindakan pengembangan pada prinsip, konsep, teori, tema lebih ditekankan untuk pemecahan problem.

\section{Model Pengembangan}

Sesuai dengan model pengembangan Lee dan Owens, pengembangan membuat rancangan prosedur pengembangan Multimedia Lee \& Owens (2004:3), yaitu: (1) Assessment/ analysis (penilaian dan analisis, (2) Design (desain), (3) Development (pengembangan), (4) Implementation (implementasi), (5) Evaluation (evaluasi)

\section{Pengertian Mobile Multimedia Learning}

Penyajian, penggabungan suara, teks, gambar bergerak, visual audio dengan tool dan link menggunakan komputer untuk dapat bernavigasi, berkomunikasi, berkarya serta interaksi dengan menggunakan alat elektronik. (Hofstetter 2001: 37). Multimedia pesan instruksional ialah keterlibatan kata dan gambar yang tersaji dalam bentuk pesan guna untuk mengingatkan pembelajaran Mayer, R. E. (2009: 4). Mobile multimedia learning adalah multimedia yang dirancang dan dikembangkan menggunakan perangkat computer untuk dapat digunakan dan diaplikasikan melalui perangkat mobile sebagai media dalam kegiatan pembelajaran.

\section{Karakteristik Mobile Multimedia Learning}

Adapun karakteristrik Multimedia Pembelajaran menurut Cepi Riyana, 2006 dalam Sukiyandari (2012) diklasifikasikan menjadi tiga karakteristik sebagai berikut: (1) Digunakannya multimedia menjadikan salah satu elemen pembelajaran di dalam kelas, (2) Digunakannya multimedia untuk bahan belajar secara mandiri, (3) Digunakannya multimedia hanya untuk media dalam pembelajaran sebagai bahan pembelajaran.

\section{Desain Mobile Multimedia Learning}

Dalam mengembangkan mobile multimedia learning, mempertimbangkan desain sangat penting untuk dilakukan, Mobile multimedia Learning memiliki desain antara lain, dikutip dari A'fza Shafie (2015) multimedia didesain sebagai berikut: (1) Menggunakan suara dan music untuk menarik perhatian anak (Jakob Nielsen, 2010), (2) Menggunakan gambar dan karakter menarik dengan efek khusus yang tidak boleh mengganggu juga ramah anak (Jakob Nielsen, 2010), (3) Menggunakan font sederhana dan relative besar (Large \& Baheshti, 2005), (4) 
Menggunakan narasi pada manusia yang ramah suara dengan bahasa yang sesuai dengan usia (Borse, Robles, \& Schwartz, 2006).

\section{Jenis Mobile Multimedia Learning}

Dalam multimedia itu dibagi ke tiga jenis. Adapun jenisnya multimedia linier, yang kedua adalah multimedia interaktif, dan yang ketiga itu multimedia hyperaktif (Binanto 2010: 26), yakni: (1) Interaktif Multimedia, pada multimedia ini, pemakai bisa mengontrol apa saja elemen multimedianya, dan kapan saja elemen multimedia tersebut akan pemakai kirimkan atau tampilkan, (2) Hiperaktif Multimedia, banyaknya tautan dan link di multimedia ini dapat menjadikan pemakai bisa mengarahkan struktur dari elemen multimedianya. Ini yang membedakan hyperaktif dengan lainnya, (3) Liniear Multimedia, menonton dan menikmati dari awal hingga akhir produk multimedia hanya itu yang bisa dilakukan pemakai saat menggunakan multimedia ini.

\section{Kelebihan Mobile Multimedia Learning}

Terdapat beberapa kelebihan dari mobile multimedia learning, antara lain menurut Munir (2012: 7) mengungkapkan kelebihan multimedia, yaitu: (1) Informasi disajikan dengan pemakaian beberapa media lain di dalamnya, (2) Jauh lebih dalam dan banyak informasi yang bisa diakses secara update, (3) Memiliki sifat multisensorik karena indra banyak yang dirangsang sehingga retensi dan perhatian pada tingkat yang baik, (4) Dengan daya ingat manusia yang terbatas, minat dan perhatian dapat ditarik, karena ini juga gabungan dari pandangan, gerakan, dan suara, (5) Benar-benar sebagai media alternative yang diperkuat oleh adanya teks, adanya suara, adanya gambar, adanya video serta juga animasi dalam pesan yang disampaikan, (6) Informasi terasampaikan meningkat dengan baik, (7) Developer dan pemakai dimungingkan untuk melakukan pembuatan, pemanipulasian, dan pengaksesan informasi adanya interaktivitas. Antara pengguna multimedia tercipta hubungan dua arah tercipta.

\section{Elemen Mobile Multimedia Learning}

Multimedia memiliki elemen-elemen penyusun yang sangat penting. Adapun elemen-elemen multimedia menurut Herman (2017) sebagai berikut: (1) Elemen teks, kegunaannya memberi suatu penyajian berupa isi, adapun penjelasan, kemudian menu, dan ada label, serta ada caption, dan masih banyak lainnya, (2) Elemen gambar, informasi secara verbal tersampaikan dengan jelas dengan adanya gambar, (3) Elemen animasi, proses tertentu tersaji oleh gambar yang terangkai dan secara urut bergerak dinamakann animasi, (4) Elemen video, suara dan gambar gerak berurutan yang mengisi suatu proses maupun suatu kejadian yang sudah direkam.

\section{Kriteria Kelayakan Mobile Multimedia Learning}

Suatu media yang dikembangkan harus mengacu pada kriteria kelayakan media. Mobile multimedia learning yang dikembangkan juga harus mengacu pada kriteria kelayakannya. Berikut adalah kriteria kelayakan media oleh Nesbit (2002) mengembangkan LORI (learning Object Review Instrument), yakni sebagai berikut: (1) Content Quality, (2) Penyesuaian penyelarasan pembelajaran, (3) Feedback dan adaptasi, (4) Motivasi, (5) Penyajian desain, (6) Kegunaan interaksi, (7) Aksesibilitas/ kemudahan digunakan, (8) Dapat digunakan kembali, (9) Pemenuhan standar.

\section{Multimedia Interaktif}

Herman (2017) menyatakan bahwa user dapat berinteraksi dengan program dalam pembelajaran manakala mencapai tujuan dari pembelajaran itu, dengan piranti computer maupun sejenisnya seperti halnya perangkat mobile, desktop, dan piranti elektronik lain yang sejenisnya, yang isinya terdapat teks, terdapat pula suatu gamba mapupun grafik, terdapat pula video di dalamnya, serta animasi juga simulasi yang semua itu dikombinasikan dan dijasikan dalam piranti lunak multi media interaktif pembelajaran. Dapat disimpulkan bahwa multimedia interaktif pembelajaran ialah multimedia yang ditambahkan elemen interaktif. Sehingga memungkinkan user untuk melakukan suatu pengontrolan terhadap elemen di piranti lunak multimedia kapanpun 
dilakukan

$$
\text { pengirimannya }
$$

serta

penampilannya.

\section{Komponen Multimedia Interaktif}

Terdapat beberapa komponen penting yang harus diperhatikan dalam pengembangannya. Menurut Herman (2017) berikut adalah komponennya: (1) Komponen Preliminary, antara lain (a) Title page. (b) Menu juga bisa disebut sebagai pilihan sajian (c) Learning review (d) Help/hint.

Komponen Content/material, antara lain (a) Control, navigation and interaction, (b) Text, sound/audio, images/pictures, video, animation and simulation. (3) Komponen Closing.

\section{Model Simulasi}

Herman (2017) dari suatu kejadian nyata, dalam bentuk suatu obyek dan suatu situasi tertentu disederhanakan dalam bentuk suatu model, inilah yang disebut simulasi. Penyimulasian tetap ada elemen yang tidak boleh dihilangkan, yakni elemen yang ada di apa yang dimulasikan. Ketidakmenyenangkannya yang ditimbulkan dari suatu resiko tidak perlu ditanggung oleh siswa saat memanipulasikannya yang dimana resiko ini bisa muncul saat melakukan hal nyata dari apa yang dimanipulasikan.

Menurut Munir (2012) Rumitnya serta telitinya bahan untuk suatu pelajaran penyajiannya itu diuji coba atau disimulasikan dengan bantuan piranti elektronik seperti piranti computer dan piranti smartphone, itulah simulation model.

\section{Simulasi Multimedia Interaktif}

Berdasarkan dari penjelasan tentang multimedia interaktif dan simulasi, maka simulasi multimedia interaktif yang dimaksudkan adalah simulasi yang dikemas dalam bentuk multimedia interaktif, atau dapat dikatakan multimedia interaktif dengan model simulasi. Simulasi multimedia interaktif berisikan tentang komponen multimedia interaktif dan penyajian materi pembelajaran dengan model simulasi. Pengguna, siswa, atau peserta didik dapat menggunakan mengoperasikan simulasi multimedia interaktif dengan menggunakan perangkat elektronik dapat berupa computer maupuan smartphone. Dalam multimedia tersebut user melakukan suatu pengontrolan terhadap elemen di piranti lunak multimedia kapanpun dilakukan pengirimannya serta penampilannya.

\section{Karakteristik Mata Pelajaran Pendidikan Jasmani Olahraga dan Kesehatan}

Kegiatan belajar bergantung pada materi yang akan ditempuh. Menurut John Travers (dalam Thobroni, 2016) tipe kegiatan belajar ada bermacam-macam antara lain: (1) Kegiatan belajar terampil dilakukan dengan berfokus pada peserta didik mempelajari melalui gerak, (2) Cakupan dari suatu pemahaman pada pengetahuan, perkembangan dari tuatu kemampuan, serta kemampuan keterampilan berpikir ialah fokus dari ranah kognitif pada kegiatan di dalam suatu pembelajaran, (3) Pemahaman dari symbol, seperti halnya pada kata, juga pada istilah, adapun pada pengertian, serta pengertian terhadap suatu peraturan, (4) Dari suatu fakta yang digeneralisasikan ke suatu konsep, ataupun adanya fakta yang dilakukan pengembangan inferensi dari bentuk logika ke bentuk konsep (5) Stimulus tertentu yang dilakukan peresponan peserta didik, itulah kegiatan namanya belajar sikap atau juga dapat dinamakan affective learning, (6) Usaha yang dilakukan mengembangkan kemampuan berpikir, inilah merupakan tipe kegiatan belajar dalam pemecahan terhadap suatu masalah.

Pembelajaran yang prosesnya didesain untuk Mengontrol kecerdasan emosional, membentuk sikap dan pribadi yang positif, berperikalu kehidupan yang sehat serta selalu aktif peningkatan pengetahuan, keterampilan dalam bergerak yang dikembangkann, kebugaran jasmani yang ditingkatkan, yang terdesain untuk aktivitas gerak, pola hidup sehat dan pengenalan lingkungan bersih, itulah Pendidikan Jasmani Olahraga dan Kesehatan.

\section{Karakteristik Siswa}

Secara perkembangan kognitif siswa, bahwa kelas III SD Insan Mulya sudah memasuki fase Concrete Operations atau operasional kongkrit. Kondisi anak pada kelas tersebut konservasi sudah dapat dipertahankan oleh anak dengan kemampuan mereka dalam mengembangkan hal itu udah cukup baik. 
Anka-angka yang memiliki konsep sudah dapat ditangani oleh mereka, pengurutan kecil besar dan sebaliknya sudah dapat dilakukan dengan baik pada fase ini. Secara memadai pengelompokkan sudah bisa dilakukan. Berdasarkan wawancara oleh guru mata pelajaran, bahwa kelas III cenderung aktif bergerak, kalau hanya teori saja mereka tidak akan paham tanpa adanya contoh praktik.

\section{METODOLOGI PENELITIAN}

Penelitian dan Pengembangan mobile multimedia learning yang nantinya dapat digunakan di Sekolah Dasar Insan Mulya Driyorejo Kabupeten Gresik. Metode penelitian yang digunakann adalah Penelitian dan Pengembangan.

\section{Model Pengembangan}

Adapun produk dalam penelitian ini menggunakan model pengembangan multimedia Lee \& Owens dengan tahapan sebagai berikut: (1) Tahap Penilaian/Analisis, Pada tahap ini dilakukan analisis kebutuhan guna untuk menentukan tujuan, mengidentifikasi perbedaan antara kindisi actual dan yang diinginkan kemudian menetapkan prioritas tindakan (Roadman, 1991). Pengumpulan data Analisis kebutuhan dilakukan melalui wawancara langsung, meliputi analisis peserta didik meliputi identifikasi latar belakang, karakteristik pembelajaran, dan keterampilan prasyarat peserta didik, analisis teknologi meliputi identifikasi ketersediaan teknologi yang ada, analisis tugas meliputi hasil belajar siswa, analisis kejadian penting meliputi keterampilan atau pengetahuan apa yang harus ditargetkan dalam intervensi multimedia atau program multimedianya, analisis situasi meliputi identifikasi kendala lingkungan atau organisasi yang mungkin berdampak pada tujuan dan desain multimedia, analisis tujuan meliputi karakteristik tujuan pembelajaran, analisis media meliputi pemilihan strategi penyampaian media, analisis data ketersediaan data, berupa materi pembelajaran, silabus dan RPP, serta analisis biaya meliputi identifikasi biaya pelaksanaan pengembangan. (2) Tahap Desain, Setelah melakukan mendata semua informasi dari analisis serta membuat keputusan yang diperlukan, masuklah pada tahap desain. Pada tahap ini dilakukan perencanaan proyek multimedia. Melakukan pembuatan susunan acara meliputi penjelasan tentang pengembangan yang akan dilaukan, melakukan pembuatan tim proyek meliputi pembuatan daftar peran dan tanggung jawab anggota tim proyek, melakukan pembuatanspesifikasi media meliputi jenis media, tampilan media, teks, tata bahasa, grafik, font, tema, symbol pengeditan, dan sebagainya, Melakukan desain struktur multimedia tentang pengurutan, penautan, dan navigasi yang dikembangkan dalam multimedia meliputi isi materi yang akan disajikan dalam multimedia, alir pelajaran, pembuatan diagram alur pelajaran, dan detail garis besar content untuk nantinya dibuat storyboard, Struktur control pengguna dan interaktivitas pengguna. Terakhir adalah melakukan desain konten konfigurasi, yakni tentang bagaimana elemen-elemen yang diperlukan dirancang dan dikelola. (3) Tahap Pengembangan, pada tahap ini semua desain yang telah didokumentasikan diimplementasikan selama pengembangannya. Pada tahap pengembangan dan implementasi adalah keterlibatan semua anggota tim dalam proyek pengembangan multimedia. Pembuatan storyboard, pengambilan video, pembuatan animasi, perekaman audio, pembuatan gambar, penyusunan pateri, melakukan pengeditan, diuji dan ditinjau. Pada tahap ini dilakukan mulai dari pembuatan kerangka kerja alat pengembangan dan spesifikasi pengembangan, selanjutnya melakukan pengembangan elemen media yang sesuai dengan kerangka kerja, kemudian dilakukan tinjauan dan merevisi produk, setelah itu dilakukan revisi produk. Pada tahap pengembangan dimulai dari tahap pra produksi, pada tahap ini dilakukan pembuatan naskah multimedia dengan penetapan visual, audio, dan instruksional atau isi konten. Kemudian masuk ke tapah produksi yakni dilakukan perekaman video atau pembuatan animasi, pembuatan elemen audio, perekaman audio, pembuatan konten isi materi sesuai dengan skrip, naskah dan atau standar pengembangan yang telah dibuat. Terakhir 
pada tahap pasca produksi dan review kualitas yaitu melakukan review atau perbaikan yang perlu sehingga produk dinilai layak untuk diimplementasikan dalam proses pembelajaran. Setelah semua proses dilakukan yang terakhir adalah pengemasan multimedia. (4) Implementation, pada tahap ini termasuk pada tahap pasca produksi, terdapat tiga tinjauan yang diperlukan selama pasca produksi. Yang pertama adalah tinjauan standar, untuk memastikan standar yang dijelaskan dalam spesifikasi multimedia. Setelah itu tinjauan editorial untuk memastikan tidak ada kesalahan dalam tata bahasa, ejaan, spasi, atau tanda baca. Tinjauan fungsional untuk memastikan tidak ada bug dalam logika pemrograman dan tidak ada glotch di audio, video, atau grafik. Pada tahap implementasi ini dilakukan review kualitas semua segmen untuk ditinjau dan dilakukan evaluasi. Evaluasi yang dilakukan pada tahap ini adalah evaluasi oleh ahli materi dan evaluasi oleh ahli media. Hasil dari tahap pengembangan yang berupa storyboard kemudian diujikan ke ahli materi untuk menentukan kebenaran materi yang akan dimasukkan ke dalam isi materi multimedia. Setelah tahap pengembangan selesai, peneliti melakukan uji media ke ahli media yang sesuai dengan kriteria ahli media yang telah ditentukan. Uji coba ini bertujuan untuk menilai kelayakan media dari sisi teknis media yang dikembangkan. Dimana uji media dalam tahap ini peneliti telah selesai mengembangkan multimedia yang akan diujicobakan ke ahli media. (5) Evaliasi yang pada tahap ini dilakukan, yakni evaluasi yang orientasinya pada kelayakan multimedia melalui perbaikanperbaikan yang dilakukan terhadap penilaian ahli materi serta ahli media.

\section{Teknik Pengumpulan Data}

Teknik pengumpulan data dalam penelitian ini menggunakan angket. Angket Ialah teknik yang dipakai untuk kegiatan mengumpulkan data yang diaplikasikan dengan cara diberikannya sepertangkat dalam bentuk pertanyaan maupun dalam bentuk pernyataan tertulis kepada para responden untnuk mereka jawab. Dengan banyaknya responden cocok sekali penggunaan dari angket (Sugiyono, 2010: 142).
Angket yang digunakan dalam pengembangan media pembelajaran mobile learning ini adalah instrumen yang bentuknya ialah angket tertutup. Angket tertutup ini angket dimana jawabannya sudah tersedia, sehingga tindakan yang dialakukan oleh reseponden hanya tinggal memiilih jawaban yang tersedia (Arikunto, 2013: 152).

Alasan dipakainnya angket ini dalam aktivitas pengumpulan data dikarenakan, dengan terdapatnya item di dalamnya, dapat menjadikan responden memperoleh kesempatan lebih teliti lagi saat berpikir dengan item pertanyaan di angket. Disisi itu pemakaian angket jenis ini mempermudah para responden untuk memberikan jawabannya dengan lebih cepat serta kemudahaan analisis datanya terhadap semua terkumpulnya angket oleh pengembang. Angket yang pada hal ini pemakaiannya untuk dilakukan pengumpulan data penilaian ataupun tanggalan dari parah ahli yakni materi, serta media.

\section{HASIL DAN PENGEMBANGAN Penilaian/Analisis}

Pada penilaian analisis dilakukan penilaian kebutuhan dan penilaian analisis awal akhir. Penilaian kebutuhan dilakukan dengan metode wawancara secara langsung dan observasi. Pada tahap ini peneliti melakukan observasi di SD Insan Mulya Driyorejo Kabupaten Gresik. Peneliti melakukan wawancara dengan guru untuk mengetahui kesenjangan yang terjadi antara kondisi nyata dan kondisi yang diinginkan.

Analisis awal akhir meliputi analisis siswa, teknologi, analisis tugas,analisis kejadian penting, analisis situasi, analisis tujuan, analisis media, analisis ketersediaan data dan analisis biaya.

\section{a) Analisis siswa}

Karakteristik siswa kelas III Sekolah Dasar nsan Mulya berbeda-beda. Saat mata pelajaran PJOK mereka lebih cenderung menyukai kegiatan pembelajaran yang berkaitan dengan gerak dan aktivitas fisik.

Saat pembelajaran jarak jauh yang menjadi kendala adalah dalam penyampaian materi dan tugas untuk 
melakukan aktivitas fisik. Tidak adanya media yang sesuai untuk pembelajaran jarak jauh pada mata pelajaran olahraga. Sehingga siswa kesulitan melakukan gerakan yang benar.

b) Analisis Teknologi

Di Sekolah Dasar Insan Mulya saat menjalankan pembelajaran secara jarak jauh, pembelajaran dilakukan dengan menggunakan perangkat elektronik berupa smartphone. Ruang belajar yang digunakan melalui aplikasi Whatsapp dan Google Classroom untuk siswa berinteraksi dan dengan guru dan siswa lainnya saat kegiatan pembelajaran.

\section{c) Analisis tugas}

Analisis tugas meliputi hasil belajar siswa. Saat pembelajaran langsung guru menyampaikan materi secara langsung siswa masih belum ada yang paham terhadap materi. Ketika pembelajaran jarak jauh, materi dan tugas yang disampaikan guru diterima oleh orangtua terlebih daulu, orang tua ada yang mudah dan kesulitasn dalam memahami, sehingga menyapaikan ke anak sering terjadi kesalahan, hal ini menyebabkan tugas masih ada yang kurang baik.

d) Analisis kejadian penting

Analisis kejadian penting meliputi keterampilan atau pengetahuan apa yang harus ditargetkan dalam intervensi multimedia atau program multimedianya. Siswa di SD Insan Mulya Driyorejo beberapa sudah dapat mengperasikan perangkat smartphone untuk penggunaan beberapa aplikasi seperti permainan, jika aplikasi untuk kegiatan belajar masih dibantu siswa. Sehingga media yang dikembangkan nantinya dibuat semudah mungkin supaya siswa mampu mengoperasikannya sendiri.

\section{e) Analisis situasi}

Analisis situasi meliputi identifikasi kendala lingkungan atau organisasi yang mungkin berdampak pada tujuan dan desain multimedia. Pada lingkungan sekolah Dasar Insan Mulya sangat mendukung jika dibuatkan media pembelajaran yang sesuai dengan jenjang belajar, materi pembelajaran, dan situasi pembelajaran, hal ini memudahkan dalam pembuatan multimedia nantinya.

\section{f) Analisis tujuan}

Analisis tujuan meliputi karakteristik tujuan pembelajaran. Terdapat kesesuaian antara karakteristik tujuan pembelajaran dan karakteristik media yang dikembangkan. Pada tujuan pembelajaran (1) Dengan mengamati materi teks deskripsi dan gambar siswa mampu mengidentifikasi prosedur gerak dasar lokomotor dan kombinasi gerak dasar lokomotor dalam permainan dengan benar. (2) Dengan mengamati materi teks deskripsi dan gambar, siswa mampu mempraktifkkan prosedur gerak dasar loomotor dan kombinasi gerak dasar lokomotor dalam permainan dengan benar. Dilihat dari analisis tujuan pembelajaran memiliki karakteristik bahwa: (1) Memerlukan media elektronik supaya siswa dapat mengakses dan mempelajari materi teks deskripsi dan gambar dari guru dalam pembelajaran jarak jauh secara mandiri. (2) Siswa dalam mengamati, memahami, dan mengidentifikasi informasi tentang gerak dasar lokomotor dan kombinasi gerak dasar lokomotor dalam pembelajaran jarak jauh secara mandiri. (3) Materi gerak dasar lokomotor dan kombinasi gerak dasar lokomotor merupakan pembelajaran olahraga yang dilakukan melalui aktivitas gerak. Dalam gerakan olahraga harus dilakukan secara procedural. (4) Gerakan dalam olahraga harus dilakukan dengan mengamati proses gerakan dengan benar supaya siswa dapat mempraktikkan gerakan tersebut dengan benar pula. (5) Pembelajaran olahraga yang dilakukan jarak jauh secara mandiri memerlukan media yang interaktif yang dapat menjelaskan proses gerakan detail dan procedural berupa visual gerak, supaya siswa dapat memperhatikan dengan jelas proses gerakan olahraga dan siswa dapat mempraktikkan prosedur gerakan tersebut dengan benar. (6) Dalam menjelaskan gerakan olahraga secara procedural harus 
secara rinci, dalam pembelajaran jarak jauh secara mandiri, dibutuhkan media interaktif yang dapat menjelaskan gerakan tersebut dalam bentuk visual untuk menjelaskan proses gerakan secara visual, audio untuk menjelaskan tentang gerakan yang divisualkan, dan teks untuk menambahkan keterangan lain pada gerakan olahraga tersebut supaya lebih jelas dan terperinci.

g) Analisis media

Analisis media meliputi pemilihan strategi penyampaian media. Strategi dalam penyampaian media akan disampaikan oleh guru kepada walimurid melalui Wthatsapp dan Google Classroom.

\section{h) Analisis ketersediaan data}

Analisis data ketersediaan data, berupa materi pembelajaran, silabus dan RPP. Di Sekolah Dasar Insan Mulya terdapat perangkat pembelajarn yang lengkap mulai dari silabus, RPP hingga materi pembelajaran. Hal ini memudahkan dalam pembuatan multimedia.

\section{i) Analisis biaya}

Analisis biaya meliputi identifikasi biaya pelaksanaan pengembangan. Beberapa biaya akan dikeluarkan untuk pembuatan multimedia pada pembuatan animasi.

\section{Desain}

Pada tahap desain dilakukan perencaan proyek multimedia, dengan rincian sebagai berikut.

Tabel 1 Perencanaan Proyek Multimedia

\begin{tabular}{|c|c|c|}
\hline No. & Kegiatan & Waktu \\
\hline 1. & Pembuatan tim proyek & 1 hari \\
\hline 2. & $\begin{array}{c}\text { Koordinasi dan penyusunan } \\
\text { desain materi dengan guru }\end{array}$ & 1 hari \\
\hline 3. & $\begin{array}{c}\text { Koordinasi desain animasi } \\
\text { dengan animator }\end{array}$ & 1 hari \\
\hline 4. & $\begin{array}{c}\text { Penyusunan spesifikasi } \\
\text { media }\end{array}$ & 1 hari \\
\hline 5. & $\begin{array}{c}\text { Membuat desain struktur } \\
\text { multimedia }\end{array}$ & 1 hari \\
\hline
\end{tabular}

Pembentukan tim proyek yang dilakukan pada tahapan ini guna untuk pembagian tugas dalam pengerjaan multimedia dengan rincian sebagai berikut.

Tabel 2 Tim Proyek Multimedia

\begin{tabular}{|c|c|c|}
\hline No. & Nama & Tugas \\
\hline 1. & $\begin{array}{c}\text { Nurreza Alvian } \\
\text { Herdianto }\end{array}$ & $\begin{array}{c}\text { Penyusun desain } \\
\text { materi }\end{array}$ \\
\hline 2. & Abdul Mujib & $\begin{array}{c}\text { Penyusun desain } \\
\text { materi }\end{array}$ \\
\hline 3. & $\begin{array}{c}\text { Ryan Akmal } \\
\text { Subagja }\end{array}$ & Animator \\
\hline 4. & $\begin{array}{c}\text { Muhammad } \\
\text { Kartika } \\
\text { Dewantoro }\end{array}$ & $\begin{array}{c}\text { Desain Struktur, } \\
\text { Desain } \\
\text { Storyboard, dan } \\
\text { Developer }\end{array}$ \\
\hline
\end{tabular}

Selanjutnya adalah melakukan desain konten konfigurasi, yakni tentang bagaimana elemen-elemen yang diperlukan dirancang dan dikelola.

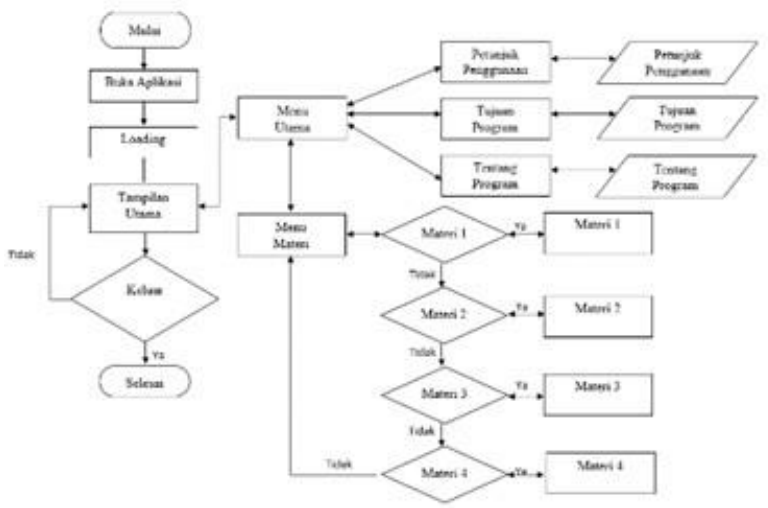

Gambar 1 Flowchart Mobile Multimedia Learning

\section{Pengembangan}

Pada tahap ini semua desain yang telah didokumentasikan diimplementasikan selama pengembangannya. Pada tahap pengembangan dan implementasi adalah keterlibatan semua anggota tim dalam proyek pengembangan multimedia. Pembuatan storyboard, pembuatan animasi, perekaman audio, pembuatan gambar, penyusunan materi, melakukan pengeditan.

Pada tahap pengembangan dimulai dari tahap pra produksi, pada tahap ini dilakukan pembuatan naskah multimedia dengan penetapan visual, audio, dan instruksional atau isi konten.

Tabel 3 Naskah Multimedia

\begin{tabular}{|l|l|}
\hline Judul & : Pendidikan Jasmani Olahraga \\
Program & \begin{tabular}{l} 
dan Kesehatan \\
\hline
\end{tabular}
\end{tabular}




\begin{tabular}{|c|c|c|}
\hline & \multicolumn{2}{|c|}{$\begin{array}{l}\text { Kombinasi Berjalan Berlari dan } \\
\text { Meloncat }\end{array}$} \\
\hline Frame & \multicolumn{2}{|l|}{ : Loading } \\
\hline $\begin{array}{l}\text { No. } \\
\text { Frame }\end{array}$ & \multicolumn{2}{|l|}{$: 1$} \\
\hline Halaman & \multicolumn{2}{|l|}{$: 1$} \\
\hline \multicolumn{2}{|c|}{$\begin{array}{l}\text { Keterangan Tampilan: } \\
\text { Layar loading sebelum } \\
\text { masuk ke tampilan utama }\end{array}$} & \multirow[t]{2}{*}{$\begin{array}{l}\text { Narasi/Audio: } \\
\text { Tidak ada }\end{array}$} \\
\hline \multicolumn{2}{|c|}{$\begin{array}{l}\text { Keterangan } \\
\text { Animasi/Video: } \\
\text { Muncul Logo SD Insan } \\
\text { Mulya }\end{array}$} & \\
\hline $\begin{array}{l}\text { Judul } \\
\text { Program }\end{array}$ & \multicolumn{2}{|c|}{$\begin{array}{l}\text { : Pendidikan Jasmani Olahraga } \\
\text { dan Kesehatan } \\
\text { Kombinasi Berjalan Berlari dan } \\
\text { Meloncat }\end{array}$} \\
\hline Frame & \multicolumn{2}{|c|}{ : Halaman Utama } \\
\hline $\begin{array}{l}\text { No. } \\
\text { Frame }\end{array}$ & \multicolumn{2}{|l|}{$: 1$} \\
\hline Halaman & \multicolumn{2}{|l|}{$: 2$} \\
\hline \multicolumn{2}{|c|}{$\begin{array}{l}\text { Keterangan Tampilan: } \\
\text { Halaman utama terdapat } \\
\text { judul program, dan dua } \\
\text { tombol, yakni tombol } \\
\text { mulai untuk masuk ke } \\
\text { halaman menu, dan tombol } \\
\text { keluar untuk keluar dari } \\
\text { aplikasi }\end{array}$} & $\begin{array}{l}\text { Narasi/Audio: } \\
\text { Musik latar } \\
\text { belakang }\end{array}$ \\
\hline \multicolumn{2}{|c|}{$\begin{array}{l}\text { Keterangan } \\
\text { Animasi/Video: } \\
\text { Pohon, rumput, pagar, } \\
\text { awan muncul dengan } \\
\text { adanya pergerakan } \\
\text { Anak berlari dari sisi } \\
\text { kanan layar menuju sisi } \\
\text { kiri layar }\end{array}$} & \\
\hline $\begin{array}{l}\text { Judul } \\
\text { Program }\end{array}$ & \multicolumn{2}{|c|}{$\begin{array}{l}\text { : Pendidikan Jasmani Olahraga } \\
\text { dan Kesehatan } \\
\text { Kombinasi Berjalan Berlari dan } \\
\text { Meloncat }\end{array}$} \\
\hline Frame & \multicolumn{2}{|c|}{ : Halaman Utama } \\
\hline $\begin{array}{l}\text { No. } \\
\text { Frame }\end{array}$ & \multicolumn{2}{|l|}{$: 1$} \\
\hline
\end{tabular}

\begin{tabular}{|c|c|c|}
\hline \multicolumn{3}{|c|}{\begin{tabular}{|l|l|} 
Halaman & $: 3$ \\
\end{tabular}} \\
\hline \multicolumn{2}{|c|}{$\begin{array}{l}\text { Keterangan Tampilan: } \\
\text { Halaman menu terdapat } \\
\text { beberapa tombol untuk } \\
\text { mengakses masing-masing } \\
\text { fungsi tombol. Terdapat } \\
\text { tombol prasyarat, tombol } \\
\text { rangkuman, tombol } \\
\text { petunjuk, tombol identitas, } \\
\text { tombol tujuan, tombol } \\
\text { penutup, tombol materi, } \\
\text { tombol pengembang, dan } \\
\text { tombol kembali }\end{array}$} & $\begin{array}{l}\text { Narasi/Audio: } \\
\text { Musik latar } \\
\text { belakang }\end{array}$ \\
\hline \multicolumn{2}{|c|}{$\begin{array}{l}\text { Keterangan } \\
\text { Animasi/Video: } \\
\text { Pohon, rumput, pagar, } \\
\text { awan muncul dengan } \\
\text { adanya pergerakan }\end{array}$} & \\
\hline $\begin{array}{l}\text { Judul } \\
\text { Program }\end{array}$ & \multicolumn{2}{|c|}{$\begin{array}{l}\text { : Pendidikan Jasmani Olahraga } \\
\text { dan Kesehatan } \\
\text { Kombinasi Berjalan Berlari dan } \\
\text { Meloncat }\end{array}$} \\
\hline Frame & \multicolumn{2}{|c|}{ : Halaman Prasyarat } \\
\hline $\begin{array}{l}\text { No. } \\
\text { Frame }\end{array}$ & \multicolumn{2}{|c|}{$: 1$} \\
\hline Halaman & \multicolumn{2}{|l|}{$: 3$} \\
\hline \multicolumn{2}{|c|}{$\begin{array}{l}\text { Keterangan Tampilan: } \\
\text { Bersisi tentang prasyarat } \\
\text { siswa } \\
\text { mempelajari sebelum } \\
\text { kombinasi berjalan berlari } \\
\text { dan meloncat }\end{array}$} & \multirow[t]{2}{*}{$\begin{array}{l}\text { Narasi/Audio: } \\
\text { Musik latar } \\
\text { belakang }\end{array}$} \\
\hline \multicolumn{2}{|c|}{$\begin{array}{l}\text { Keterangan } \\
\text { Animasi/Video: } \\
\text { Pohon, rumput, pagar, } \\
\text { awan muncul dengan } \\
\text { adanya pergerakan }\end{array}$} & \\
\hline $\begin{array}{l}\text { Judul } \\
\text { Program }\end{array}$ & \multicolumn{2}{|c|}{$\begin{array}{l}\text { Pendidikan Jasmani Olahraga } \\
\text { dan Kesehatan } \\
\text { Kombinasi Berjalan Berlari dan } \\
\text { Meloncat }\end{array}$} \\
\hline Frame & \multicolumn{2}{|c|}{ : Halaman Anjuran } \\
\hline $\begin{array}{l}\text { No. } \\
\text { Frame }\end{array}$ & \\
\hline Halaman & \multicolumn{2}{|l|}{$: 3$} \\
\hline
\end{tabular}




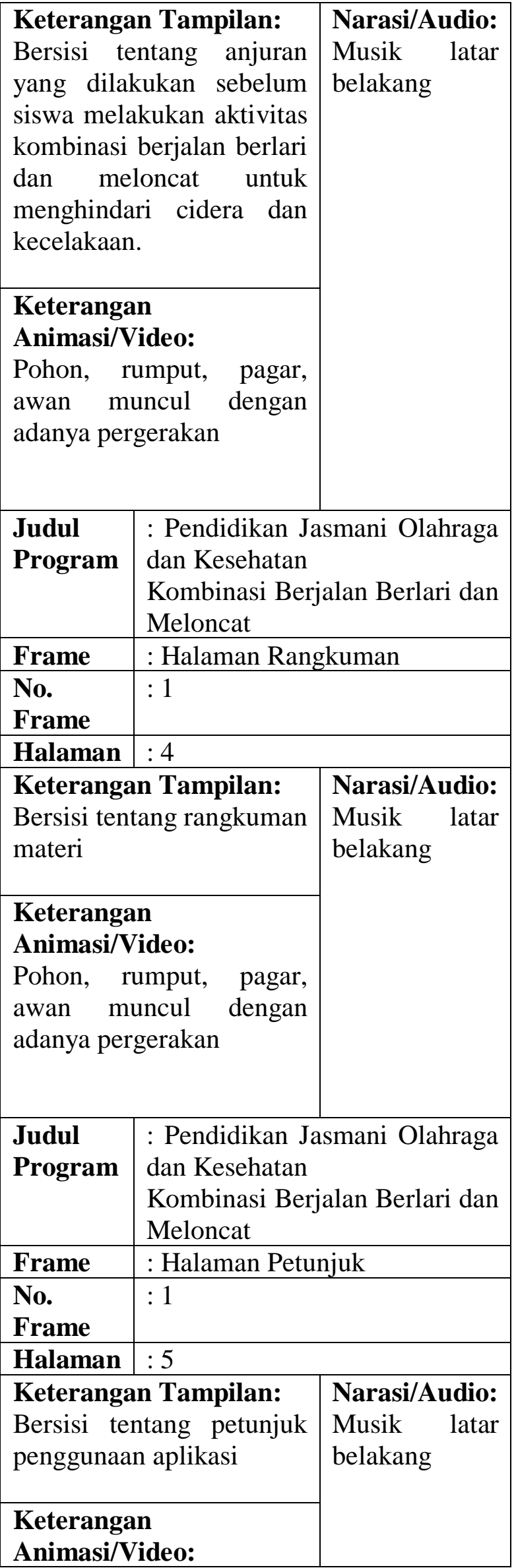

\begin{tabular}{|c|c|c|}
\hline \multicolumn{2}{|c|}{$\begin{array}{l}\text { Pohon, rumput, pagar, } \\
\text { awan muncul dengan } \\
\text { adanya pergerakan }\end{array}$} & \\
\hline $\begin{array}{l}\text { Judul } \\
\text { Program }\end{array}$ & \multicolumn{2}{|c|}{$\begin{array}{l}\text { : Pendidikan Jasmani Olahraga } \\
\text { dan Kesehatan } \\
\text { Kombinasi Berjalan Berlari dan } \\
\text { Meloncat }\end{array}$} \\
\hline Frame & \multicolumn{2}{|c|}{ : Halaman Identitas } \\
\hline $\begin{array}{l}\text { No. } \\
\text { Frame }\end{array}$ & \multicolumn{2}{|c|}{$: 1$} \\
\hline Halaman & \multicolumn{2}{|l|}{$: 6$} \\
\hline \multicolumn{2}{|c|}{$\begin{array}{l}\text { Keterangan Tampilan: } \\
\text { Bersisi tentang identitas } \\
\text { progam pembelajaran }\end{array}$} & \multirow[t]{2}{*}{$\begin{array}{l}\text { Narasi/Audio: } \\
\text { Musik latar } \\
\text { belakang }\end{array}$} \\
\hline \multicolumn{2}{|c|}{$\begin{array}{l}\text { Keterangan } \\
\text { Animasi/Video: } \\
\text { Pohon, rumput, pagar, } \\
\text { awan muncul dengan } \\
\text { adanya pergerakan }\end{array}$} & \\
\hline $\begin{array}{l}\text { Judul } \\
\text { Program }\end{array}$ & \multicolumn{2}{|c|}{$\begin{array}{l}\text { : Pendidikan Jasmani Olahraga } \\
\text { dan Kesehatan } \\
\text { Kombinasi Berjalan Berlari dan } \\
\text { Meloncat }\end{array}$} \\
\hline Frame & \multicolumn{2}{|c|}{ : Halaman Tujuan } \\
\hline $\begin{array}{l}\text { No. } \\
\text { Frame }\end{array}$ & \multicolumn{2}{|l|}{$: 1$} \\
\hline Halaman & \multicolumn{2}{|l|}{$: 7$} \\
\hline \multicolumn{2}{|c|}{$\begin{array}{l}\text { Keterangan Tampilan: } \\
\text { Bersisi tentang tujuan } \\
\text { pembelajaran }\end{array}$} & \multirow[t]{2}{*}{$\begin{array}{l}\text { Narasi/Audio: } \\
\text { Musik latai } \\
\text { belakang }\end{array}$} \\
\hline \multicolumn{2}{|c|}{$\begin{array}{l}\text { Keterangan } \\
\text { Animasi/Video: } \\
\text { Pohon, rumput, pagar, } \\
\text { awan muncul dengan } \\
\text { adanya pergerakan }\end{array}$} & \\
\hline $\begin{array}{l}\text { Judul } \\
\text { Program }\end{array}$ & \multicolumn{2}{|c|}{$\begin{array}{l}\text { : Pendidikan Jasmani Olahraga } \\
\text { dan Kesehatan } \\
\text { Kombinasi Berjalan Berlari dan } \\
\text { Meloncat }\end{array}$} \\
\hline Frame & \multicolumn{2}{|c|}{ : Halaman Penutup } \\
\hline $\begin{array}{l}\text { No. } \\
\text { Frame }\end{array}$ & \multicolumn{2}{|l|}{$: 1$} \\
\hline
\end{tabular}




\begin{tabular}{|c|c|c|}
\hline \multicolumn{3}{|l|}{ Halaman } \\
\hline \multirow{2}{*}{\multicolumn{2}{|c|}{$\begin{array}{l}\text { Keterangan Tampilan: } \\
\text { Bersisi tentang penutup }\end{array}$}} & Narasi/Audio: \\
\hline & & $\begin{array}{l}\text { Musik latar } \\
\text { belakang }\end{array}$ \\
\hline \multicolumn{2}{|c|}{$\begin{array}{l}\text { Keterangan } \\
\text { Animasi/Video: } \\
\text { Pohon, rumput, pagar, } \\
\text { awan muncul dengan } \\
\text { adanya pergerakan }\end{array}$} & \\
\hline $\begin{array}{l}\text { Judul } \\
\text { Program }\end{array}$ & \multicolumn{2}{|c|}{$\begin{array}{l}\text { : Pendidikan Jasmani Olahraga } \\
\text { dan Kesehatan } \\
\text { Kombinasi Berjalan Berlari dan } \\
\text { Meloncat }\end{array}$} \\
\hline Frame & \multicolumn{2}{|c|}{ : Halaman Prengembang } \\
\hline $\begin{array}{l}\text { No. } \\
\text { Frame }\end{array}$ & \multicolumn{2}{|l|}{$: 1$} \\
\hline Halaman & \multicolumn{2}{|l|}{$: 9$} \\
\hline \multicolumn{2}{|c|}{$\begin{array}{l}\text { Keterangan Tampilan: } \\
\text { Bersisi tentang biodata } \\
\text { pengembang, guru, } \\
\text { developer dan animator. }\end{array}$} & $\begin{array}{l}\text { Narasi/Audio: } \\
\text { Musik latar } \\
\text { belakang }\end{array}$ \\
\hline \multicolumn{3}{|c|}{$\begin{array}{l}\text { Keterangan } \\
\text { Animasi/Video: } \\
\text { Pohon, rumput, pagar, } \\
\text { awan muncul dengan } \\
\text { adanya pergerakan }\end{array}$} \\
\hline $\begin{array}{l}\text { Judul } \\
\text { Program }\end{array}$ & \multicolumn{2}{|c|}{$\begin{array}{l}\text { : Pendidikan Jasmani Olahraga } \\
\text { dan Kesehatan } \\
\text { Kombinasi Berjalan Berlari dan } \\
\text { Meloncat }\end{array}$} \\
\hline Frame & \multicolumn{2}{|c|}{ : Halaman Materi } \\
\hline $\begin{array}{l}\text { No. } \\
\text { Frame }\end{array}$ & \multicolumn{2}{|l|}{$: 1$} \\
\hline Halaman & \multicolumn{2}{|l|}{$: 10$} \\
\hline \multicolumn{2}{|c|}{$\begin{array}{l}\text { Keterangan Tampilan: } \\
\text { Bersisi tentang beberapa } \\
\text { opsi materi yang bisa } \\
\text { dipilih, mulai dari opsi } \\
\text { materi berjalan, opsi } \\
\text { materi berlari, opsi materi } \\
\text { meloncat, dan opsi materi } \\
\text { kombinasi }\end{array}$} & $\begin{array}{l}\text { Narasi/Audio: } \\
\text { Musik latar } \\
\text { belakang }\end{array}$ \\
\hline $\begin{array}{l}\text { Keteran } \\
\text { Animasi }\end{array}$ & . & \\
\hline
\end{tabular}

\begin{tabular}{|c|c|c|}
\hline \multicolumn{2}{|c|}{$\begin{array}{l}\text { Pohon, rumput, pagar, } \\
\text { awan muncul dengan } \\
\text { adanya pergerakan }\end{array}$} & \\
\hline $\begin{array}{l}\text { Judul } \\
\text { Program }\end{array}$ & \multicolumn{2}{|c|}{$\begin{array}{l}\text { : Pendidikan Jasmani Olahraga } \\
\text { dan Kesehatan } \\
\text { Kombinasi Berjalan Berlari dan } \\
\text { Meloncat }\end{array}$} \\
\hline Frame & \multicolumn{2}{|c|}{ : Halaman Materi Berjalan } \\
\hline $\begin{array}{l}\text { No. } \\
\text { Frame }\end{array}$ & \multicolumn{2}{|c|}{$: 1$} \\
\hline $\begin{array}{l}\text { Halaman }: 11 \\
\text { Keterangan Tampilan: }\end{array}$ & \multicolumn{2}{|l|}{$: 11$} \\
\hline \multicolumn{2}{|c|}{$\begin{array}{l}\text { Bersisi tentang materi } \\
\text { gerak berjalan }\end{array}$} & $\begin{array}{l}\text { Narasi/Audio: } \\
\text { Musik latar } \\
\text { belakang, } \\
\text { Narasi }\end{array}$ \\
\hline \multicolumn{2}{|c|}{$\begin{array}{l}\text { Keterangan } \\
\text { Animasi/Video: } \\
\text { Anak yang pada posisi } \\
\text { awal adalah diam dengan } \\
\text { bernafas. } \\
\text { Anak melakukan aktivitas } \\
\text { berjalan saat diperintahkan } \\
\text { dengan mengklik tombol } \\
\text { berjalan. }\end{array}$} & $\begin{array}{l}\text { pengertian } \\
\text { Narasi Cara } \\
\text { melakukan }\end{array}$ \\
\hline $\begin{array}{l}\text { Judul } \\
\text { Program }\end{array}$ & \multicolumn{2}{|c|}{$\begin{array}{l}\text { : Pendidikan Jasmani Olahraga } \\
\text { dan Kesehatan } \\
\text { Kombinasi Berjalan Berlari dan } \\
\text { Meloncat }\end{array}$} \\
\hline Frame & \multicolumn{2}{|c|}{ : Halaman Materi Berlari } \\
\hline $\begin{array}{l}\text { No. } \\
\text { Frame }\end{array}$ & \multicolumn{2}{|c|}{$: 1$} \\
\hline \multicolumn{3}{|c|}{\begin{tabular}{l|l} 
Halaman & $: 12$
\end{tabular}} \\
\hline \multicolumn{2}{|c|}{$\begin{array}{l}\text { Bersisi tentang materi } \\
\text { gerak berlari }\end{array}$} & $\begin{array}{l}\text { Narasi/Audio: } \\
\text { Musik latar } \\
\text { belakang, } \\
\text { Narasi }\end{array}$ \\
\hline \multicolumn{2}{|c|}{$\begin{array}{l}\text { Keterangan } \\
\text { Animasi/Video: } \\
\text { Anak yang pada posisi } \\
\text { awal adalah diam dengan } \\
\text { bernafas. } \\
\text { Anak melakukan aktivitas } \\
\text { berlari saat diperintahkan } \\
\text { dengan mengklik tombol } \\
\text { berlari.. }\end{array}$} & $\begin{array}{l}\text { pengertian } \\
\text { Narasi Cara } \\
\text { melakukan }\end{array}$ \\
\hline
\end{tabular}




\begin{tabular}{|c|c|c|}
\hline $\begin{array}{l}\text { Judul } \\
\text { Program }\end{array}$ & \multicolumn{2}{|c|}{$\begin{array}{l}\text { : Pendidikan Jasmani Olahraga } \\
\text { dan Kesehatan } \\
\text { Kombinasi Berjalan Berlari dan } \\
\text { Meloncat }\end{array}$} \\
\hline Frame & \multicolumn{2}{|c|}{ : Halaman Materi Meloncat } \\
\hline $\begin{array}{l}\text { No. } \\
\text { Frame }\end{array}$ & \multicolumn{2}{|c|}{$: 1$} \\
\hline Halaman & \multicolumn{2}{|l|}{$: 13$} \\
\hline \multicolumn{2}{|c|}{$\begin{array}{l}\text { Bersisi tentang materi } \\
\text { gerak meloncat }\end{array}$} & \multirow{2}{*}{$\begin{array}{l}\text { Narasi/Audio: } \\
\text { Musik latar } \\
\text { belakang, } \\
\text { Narasi } \\
\text { pengertian } \\
\text { Narasi Cara } \\
\text { melakukan }\end{array}$} \\
\hline \multicolumn{2}{|c|}{$\begin{array}{l}\text { Keterangan } \\
\text { Animasi/Video: } \\
\text { Anak yang pada posisi } \\
\text { awal adalah diam dengan } \\
\text { bernafas. } \\
\text { Anak melakukan aktivitas } \\
\text { meloncat raat } \\
\text { diperintahkan rengan } \\
\text { mengklik } \\
\text { meloncat. }\end{array}$} & \\
\hline $\begin{array}{l}\text { Judul } \\
\text { Program }\end{array}$ & \multicolumn{2}{|c|}{$\begin{array}{l}\text { : Pendidikan Jasmani Olahraga } \\
\text { dan Kesehatan } \\
\text { Kombinasi Berjalan Berlari dan } \\
\text { Meloncat }\end{array}$} \\
\hline Frame & \multicolumn{2}{|c|}{ : Halaman Materi Kombinasi } \\
\hline \begin{tabular}{|l|} 
No. \\
Frame \\
\end{tabular} & \multicolumn{2}{|c|}{$: 1$} \\
\hline Halaman & \multicolumn{2}{|l|}{$: 14$} \\
\hline \multicolumn{2}{|c|}{$\begin{array}{l}\text { Keterangan Tampilan: } \\
\text { Bersisi tentang materi } \\
\text { gerak kombinasi berjalan, } \\
\text { berlari dan meloncat }\end{array}$} & $\begin{array}{l}\text { Narasi/Audio: } \\
\text { Musik latar } \\
\text { belakang, } \\
\text { Narasi } \\
\text { pengertian }\end{array}$ \\
\hline \multicolumn{2}{|c|}{$\begin{array}{l}\text { Keterangan } \\
\text { Animasi/Video: } \\
\text { Anak yang pada posisi } \\
\text { awal adalah diam dengan } \\
\text { bernafas. } \\
\text { Anak melakukan aktivitas } \\
\text { gerak kombinasi berjalan, } \\
\text { berlari dan meloncat n saat } \\
\text { diperintahkan dengan } \\
\text { mengklik tombol gerak }\end{array}$} & $\begin{array}{l}\text { Narasi Cara } \\
\text { melakukan }\end{array}$ \\
\hline
\end{tabular}

kombinasi berjalan, berlari dan meloncat.

Kemudian masuk ke tahap produksi yakni dilakukan perekaman video atau pembuatan animasi, pembuatan elemen audio, perekaman audio, pembuatan konten isi materi sesuai dengan skrip, naskah dan atau standar pengembangan yang telah dibuat. Terakhir pada tahap pasca produksi dan review kualitas yaitu melakukan review ulang terhadap semua aspek dan elemen sebelum nantinya dilakukan validasi.

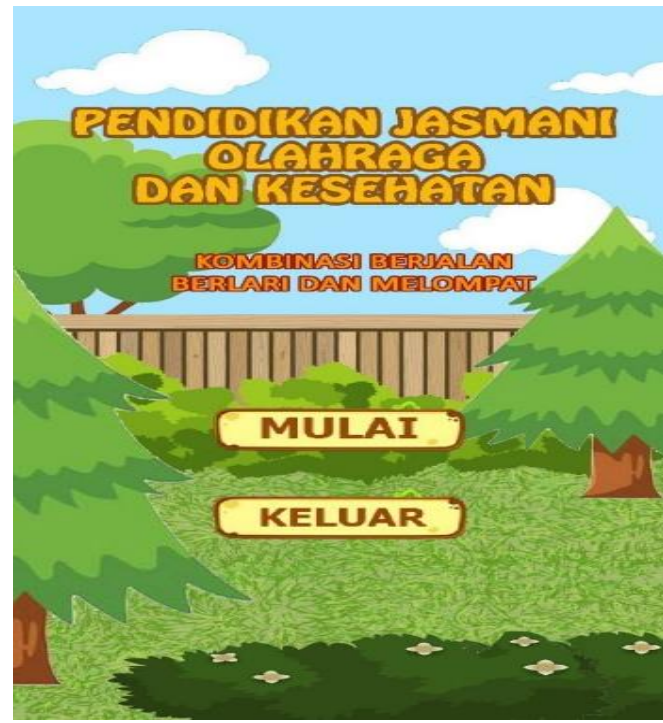

Gambar 2 Halaman Utama

FATUTHEW JESMEW Qนलैदिल

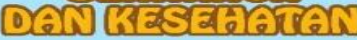
CZOMGBOCASO BERRIALAN

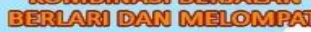

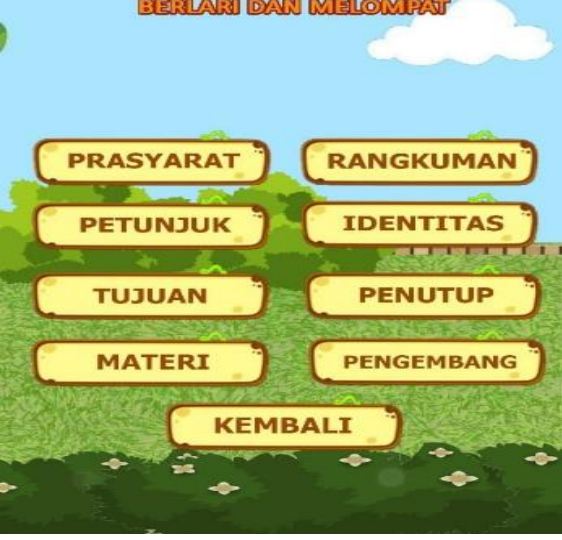

Gambar 3 Halaman Menu 


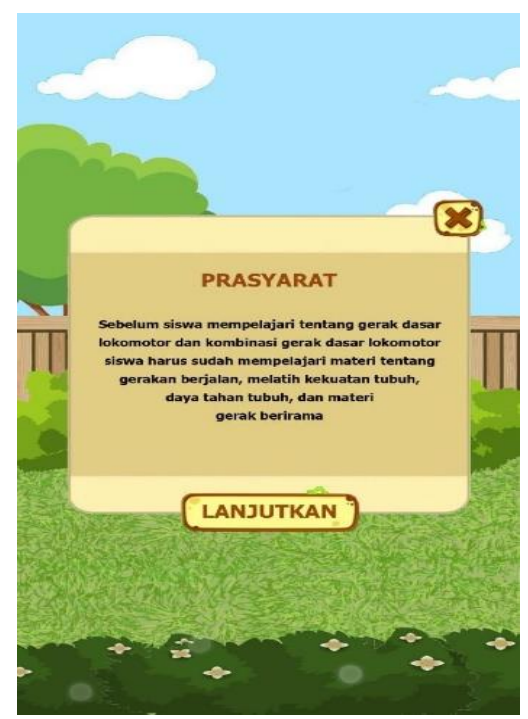

Gambar 4 Halaman Prasyarat

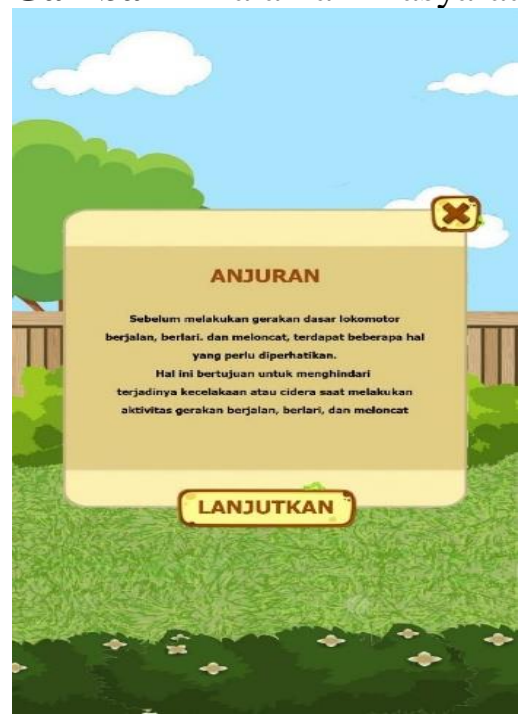

Gambar 5 Halaman Anjuran

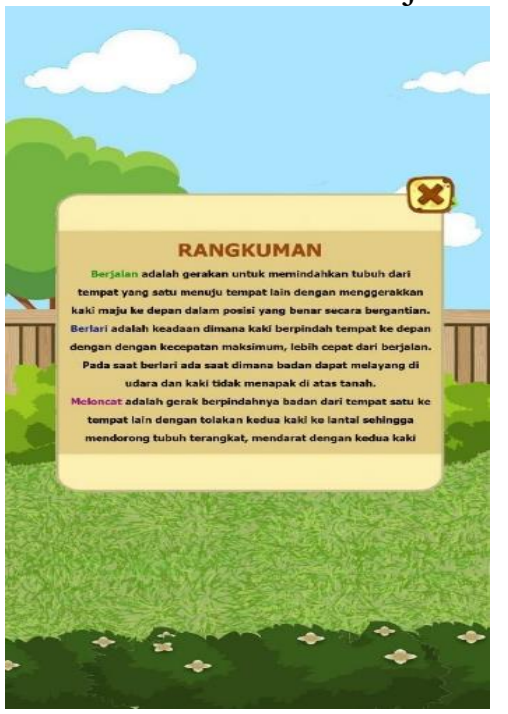

Gambar 6 Halaman Rangkuman

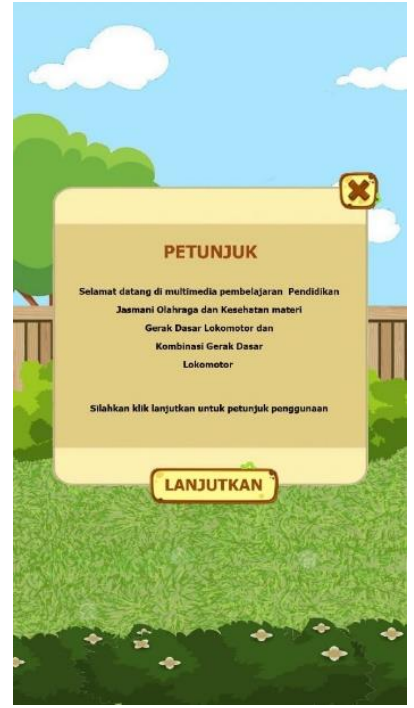

Gambar 7 Halaman Petunjuk

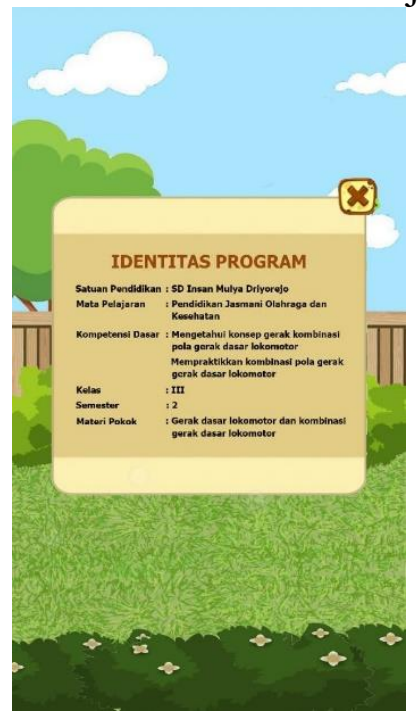

Gambar 8 Halaman Identitas

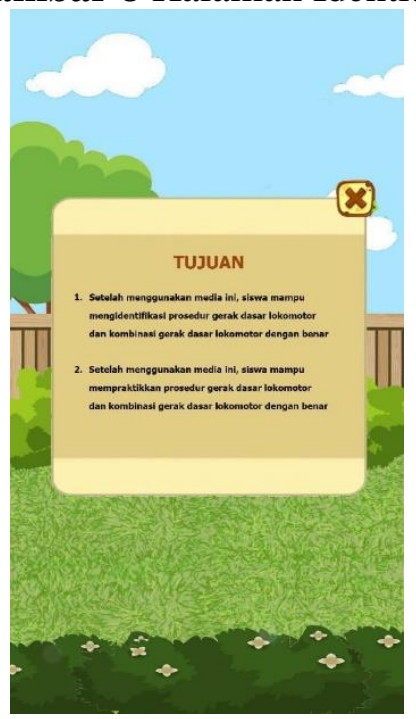

Gambar 9 Halaman Tujuan 


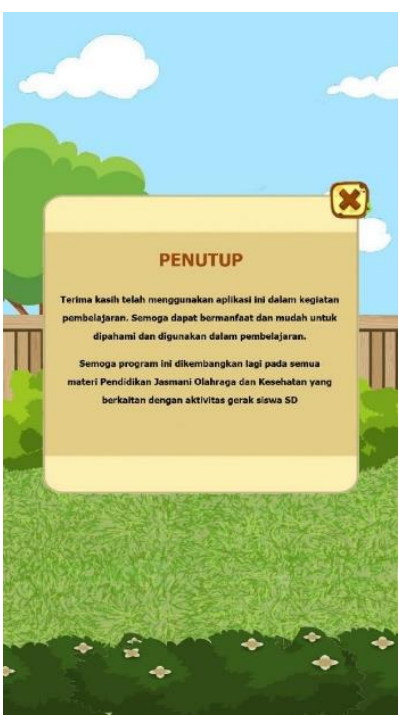

Gambar 10 Halaman Penutup

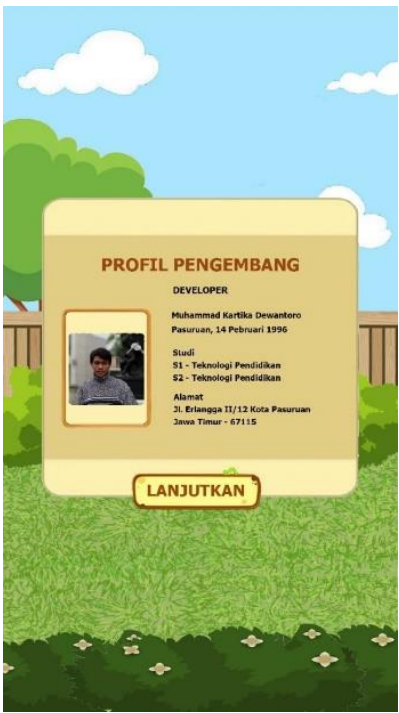

Gambar 11 Halaman Pengembang

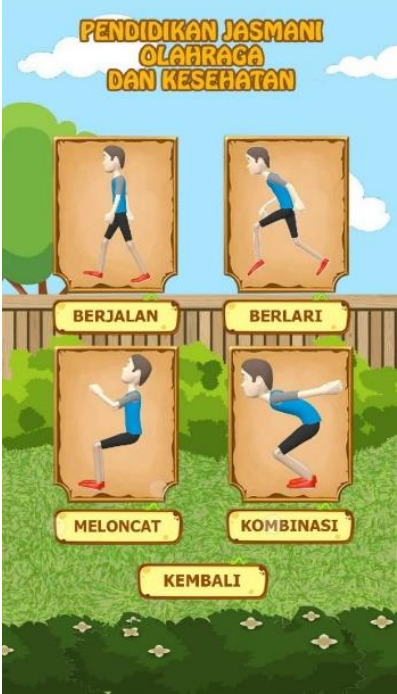

Gambar 12 Halaman Materi

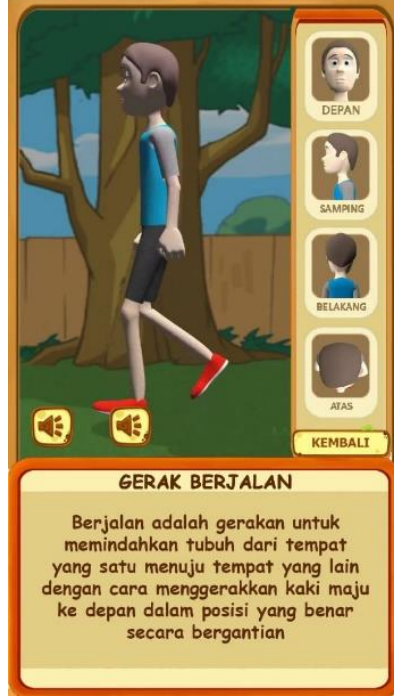

Gambar 13 Halaman Materi Berjalan

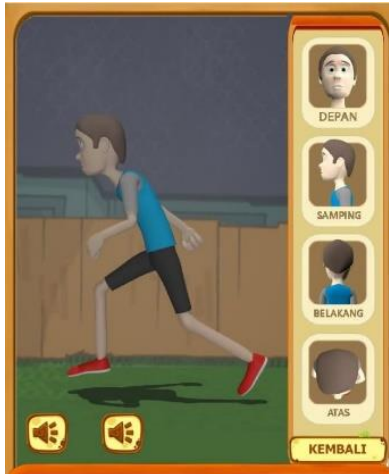

GERAK BERLARI

Berlari adalah keadaan dimana kaki berpindah tempat ke depan dengan berjalan.

Pada gerakan berlari ada sact melayang di udara sehingga kaki tidak menapak ke tanah.

\section{Gambar 14 Halaman Materi Berlari}

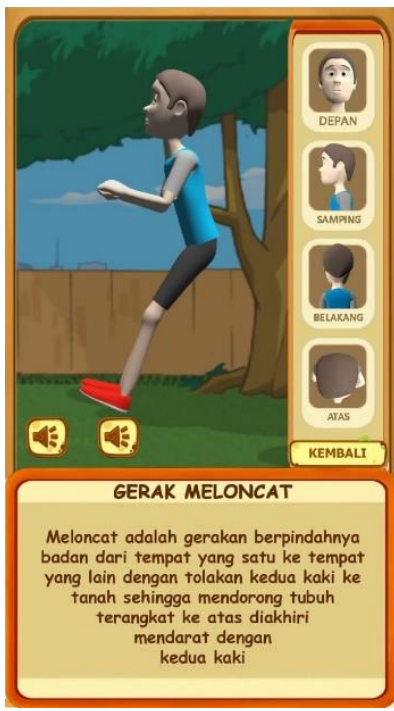

Gambar 15 Halaman Materi Meloncat 


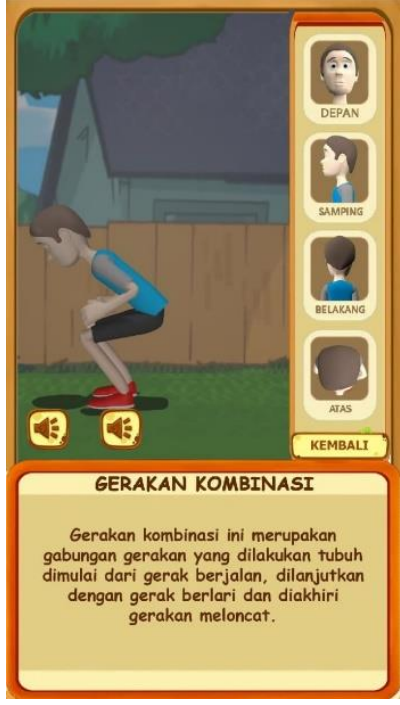

Gambar 16 Halaman Materi Gerakan Kombinasi

Setelah semua proses dilakukan yang terakhir adalah pengemasan multimedia dalam format apk untuk selanjutnya dilakukan validasi terhadap ahli materi dan media.

\section{Implementasi}

Pada tahap ini termasuk pada tahap pasca produksi, terdapat tiga tinjauan yang diperlukan selama pasca produksi. Yang pertama adalah tinjauan standar, untuk memastikan standar yang dijelaskan dalam spesifikasi multimedia. Setelah itu tinjauan editorial untuk memastikan tidak ada kesalahan dalam tata bahasa, ejaan, spasi, atau tanda baca. Tinjauan fungsional untuk memastikan tidak ada bug dalam logika pemrograman dan tidak ada glotch di audio, video, atau grafik. Dalam tahap ini peneliti telah selesai mengembangkan multimedia yang akan diujicobakan ke ahli materi dan ahli media. Uji coba ini bertujuan untuk menilai kelayakan media.

\section{a) Uji Coba Ahli Materi}

Pengembangan ini menghasilkan sebuah produk media yang nantinya dapat digunakan guru sebagai sarana atau alat untuk menyampaikan materi pelajaran kepada siswa yang dikemas dalam bentuk mobile learning. Oleh karena itu materi harus sesuai dengan criteria yang dibutuhkan siswa. Ahli materi berasal dari dua orang dosen jurusan Pendidikan Jasmani Kesehatan dan Rekreasi UNESA, adapun ahli materi tersebut adalah Ibu
Fifukha Dwi Khory S.Pd., M.Pd. sebagai ahli materi 1 dan Bapak Afifan Yulfadinata, S.Pd., M.Pd. sebagai ahli materi 2.

Tabel 4 Penilaian Ahli Materi I

\begin{tabular}{|c|c|c|c|c|c|c|c|}
\hline \multirow[b]{2}{*}{ Variabel } & \multirow{2}{*}{$\begin{array}{c}\text { Sub } \\
\text { Varia } \\
\text { bel }\end{array}$} & \multirow{2}{*}{$\begin{array}{c}\text { Sub- } \\
\text { sub } \\
\text { variabe } \\
\text { l }\end{array}$} & \multirow[b]{2}{*}{ Indikator } & \multicolumn{4}{|c|}{ Nilai } \\
\hline & & & & 1 & 2 & 3 & 4 \\
\hline \multirow[t]{9}{*}{$\begin{array}{l}\text { Pengemb } \\
\text { angan } \\
\text { Mobile } \\
\text { Multimedi } \\
a \\
\text { Learning }\end{array}$} & \multirow[t]{9}{*}{$\begin{array}{l}\text { Segi } \\
\text { isi } \\
\text { mater } \\
\text { i }\end{array}$} & $\begin{array}{c}\text { Sesuai } \\
\text { dengan } \\
\text { tujuan } \\
\text { yang } \\
\text { telah } \\
\text { dirumus } \\
\text { kan }\end{array}$ & $\begin{array}{l}\text { Materi } \\
\text { sesuai } \\
\text { dengan } \\
\text { tujuan } \\
\text { pembelaja } \\
\text { ran yang } \\
\text { telah } \\
\text { dirumuska } \\
\text { n }\end{array}$ & & & & $\sqrt{ }$ \\
\hline & & \multirow{4}{*}{$\begin{array}{c}\text { Isi } \\
\text { Materi }\end{array}$} & $\begin{array}{l}\text { Bahasa } \\
\text { yang } \\
\text { digunakan } \\
\text { mudah } \\
\text { dimengerti }\end{array}$ & & & & $\sqrt{ }$ \\
\hline & & & $\begin{array}{l}\text { Bahasa } \\
\text { yang } \\
\text { digunakan } \\
\text { sesuai } \\
\text { dengan } \\
\text { karakterist } \\
\text { ik siswa }\end{array}$ & & & & $\sqrt{ }$ \\
\hline & & & $\begin{array}{l}\text { Bahasa } \\
\text { sesuai } \\
\text { dengan } \\
\text { tingkat } \\
\text { kognitif } \\
\text { siswa }\end{array}$ & & & & $\sqrt{ }$ \\
\hline & & & $\begin{array}{l}\text { Kesesuaia } \\
\mathrm{n} \\
\text { gambar/an } \\
\text { imasi } \\
\text { pendukun } \\
\text { g materi }\end{array}$ & & & $\sqrt{ }$ & \\
\hline & & \multirow{2}{*}{$\begin{array}{c}\text { Sesuai } \\
\text { dengan } \\
\text { tingkat } \\
\text { kemam } \\
\text { puan } \\
\text { siswa }\end{array}$} & $\begin{array}{l}\text { Materi } \\
\text { mudah } \\
\text { diterima } \\
\text { oleh siswa }\end{array}$ & & & $\sqrt{ }$ & \\
\hline & & & $\begin{array}{l}\text { Materi } \\
\text { sesuai } \\
\text { dengan } \\
\text { tingkat } \\
\text { kemampu } \\
\text { an siswa }\end{array}$ & & & & $\sqrt{ }$ \\
\hline & & \multirow{2}{*}{$\begin{array}{c}\text { Tidak } \\
\text { banyak } \\
\text { kata } \\
\text { sulit }\end{array}$} & $\begin{array}{l}\text { Kata-kata } \\
\text { mudah } \\
\text { dipahami }\end{array}$ & & & & $\sqrt{ }$ \\
\hline & & & $\begin{array}{l}\text { Tidak ada } \\
\text { kata yang } \\
\text { bermakna } \\
\text { ganda }\end{array}$ & & & & $\sqrt{ }$ \\
\hline
\end{tabular}


Tabel 5 Penilaian Ahli Materi II

\begin{tabular}{|c|c|c|c|c|c|c|c|}
\hline \multirow{2}{*}{ Variabel } & \multirow{2}{*}{$\begin{array}{c}\text { Sub } \\
\text { Varia } \\
\text { bel }\end{array}$} & \multirow{2}{*}{$\begin{array}{l}\text { Sub-sub } \\
\text { variabel }\end{array}$} & \multirow{2}{*}{ Indikator } & \multicolumn{4}{|c|}{ Nilai } \\
\hline & & & & 1 & 2 & 3 & 4 \\
\hline \multirow[t]{9}{*}{$\begin{array}{c}\text { Pengemban } \\
\text { gan Mobile } \\
\text { Multimedia } \\
\text { Learning }\end{array}$} & \multirow[t]{9}{*}{$\begin{array}{l}\text { Segi } \\
\text { isi } \\
\text { materi }\end{array}$} & $\begin{array}{c}\text { Sesuai } \\
\text { dengan } \\
\text { tujuan } \\
\text { yang } \\
\text { telah } \\
\text { dirumus } \\
\text { kan }\end{array}$ & $\begin{array}{l}\text { Materi } \\
\text { sesuai } \\
\text { dengan } \\
\text { tujuan } \\
\text { pembelajar } \\
\text { an yang } \\
\text { telah } \\
\text { dirumuskan }\end{array}$ & & & & $\sqrt{ }$ \\
\hline & & \multirow{4}{*}{$\begin{array}{c}\text { Isi } \\
\text { Materi }\end{array}$} & $\begin{array}{l}\text { Bahasa } \\
\text { yang } \\
\text { digunakan } \\
\text { mudah } \\
\text { dimengerti }\end{array}$ & & & & $\sqrt{ }$ \\
\hline & & & $\begin{array}{l}\text { Bahasa } \\
\text { yang } \\
\text { digunakan } \\
\text { sesuai } \\
\text { dengan } \\
\text { karakteristi } \\
\text { k siswa }\end{array}$ & & & & $\sqrt{ }$ \\
\hline & & & $\begin{array}{l}\text { Bahasa } \\
\text { sesuai } \\
\text { dengan } \\
\text { tingkat } \\
\text { kognitif } \\
\text { siswa } \\
\end{array}$ & & & $\sqrt{ }$ & \\
\hline & & & $\begin{array}{l}\text { Kesesuaian } \\
\text { gambar/ani } \\
\text { masi } \\
\text { pendukung } \\
\text { materi }\end{array}$ & & & & $\sqrt{ }$ \\
\hline & & \multirow{2}{*}{$\begin{array}{c}\text { Sesuai } \\
\text { dengan } \\
\text { tingkat } \\
\text { kemamp } \\
\text { uan } \\
\text { siswa }\end{array}$} & $\begin{array}{l}\text { Materi } \\
\text { mudah } \\
\text { diterima } \\
\text { oleh siswa }\end{array}$ & & & & $\sqrt{ }$ \\
\hline & & & $\begin{array}{l}\text { Materi } \\
\text { sesuai } \\
\text { dengan } \\
\text { tingkat } \\
\text { kemampua } \\
\text { n siswa }\end{array}$ & & & & $\sqrt{ }$ \\
\hline & & \multirow[t]{2}{*}{$\begin{array}{c}\text { Tidak } \\
\text { banyak } \\
\text { kata sulit }\end{array}$} & $\begin{array}{l}\text { Kata-kata } \\
\text { mudah } \\
\text { dipahami }\end{array}$ & & & $\sqrt{ }$ & \\
\hline & & & $\begin{array}{l}\text { Tidak ada } \\
\text { kata yang } \\
\text { bermakna } \\
\text { ganda }\end{array}$ & & & $\sqrt{ }$ & \\
\hline
\end{tabular}

Tabel 6 Penilaian Perhitungan Penilaian Ahli Materi Setiap Butir Soal

\begin{tabular}{|c|c|c|}
\hline No. Butir & $\begin{array}{c}\text { Perhitungan Setiap } \\
\text { Aspek }\end{array}$ & Hasil \\
\hline 1 & $\frac{8}{8} \times 100 \%$ & $100 \%$ \\
\hline 2 & $\frac{8}{8} \times 100 \%$ & $100 \%$ \\
\hline 3 & $\frac{8}{8} \times 100 \%$ & $100 \%$ \\
\hline 4 & $\frac{7}{8} \times 100 \%$ & $87,5 \%$ \\
\hline 5 & $\frac{7}{8} \times 100 \%$ & $87,5 \%$ \\
\hline
\end{tabular}

\begin{tabular}{|c|c|c|}
\hline 6 & $\frac{7}{8} \times 100 \%$ & $87,5 \%$ \\
\hline 7 & $\frac{8}{8} \times 100 \%$ & $100 \%$ \\
\hline 8 & $\frac{7}{8} \times 100 \%$ & $87,5 \%$ \\
\hline 9 & $\frac{7}{8} \times 100 \%$ & $87,5 \%$ \\
\hline
\end{tabular}

Hasil perhitungan data validasi dengan ahli materi seluruh butir soal sebagai berikut:

$$
\begin{aligned}
\text { PSA } & \frac{\text { Epenilaian seluruh aspek }}{\text { Npenilaian ideal seluruh aspek }} 100 \% \\
= & \frac{8+8+8+7+7+7+8+7+7}{72} 100 \% \\
= & \frac{67}{72} 100 \% \\
= & 93,1 \%
\end{aligned}
$$

Berdasarkan hasil analisis data uji coba ahli materi tersebut, diperoleh $93,1 \%$ pada sub variable persoalan segi isi materi. Dimana pada Arikunto (2013) jika hasil analisis data didapat 93,1\% termasuk pada kategori sangat baik, maka dapat diambil kesimpulan bahwa media pembelajaran mobile learning materi perkakas tangan layak digunakan dalam hal materi pembelajaran.

\section{b) Uji Coba Ahli Media}

Penelitian ini mengembangkan media yang diperuntukkan bagi pengahar atau guru sebagai alat bantu untuk menyampaikan materi pelajaran di dalam kelas. Dalam proses produksinya, mobile learning membutuhkan desain visual yang berkualitas dan membutuhkan ahli desain media pembelajaran mobile yang tepat agar media yang dihasilkan dapat memenuhi kebutuhan sasaran. Ahli media berasal dari dua orang dosen jurusan Teknologi Pendidikan UNESA, adapun ahli media tersebut adalah Bapak Dr. Andi Kristanto, S.Pd., M.Pd. sebagai ahli media 1 dan Ibu Dr. Utari Dewi, S.Sn., M.Pd. sebagai ahli media 2. 
Terakreditasi Peringkat 4 (No. SK: 36/E/KPT/2019)

Tabel 7 Penilaian Ahli Media I

\begin{tabular}{|c|c|c|c|c|c|c|c|}
\hline \multirow[b]{2}{*}{ Variabel } & \multirow{2}{*}{$\begin{array}{c}\text { Sub } \\
\text { Vari } \\
\text { abel }\end{array}$} & \multirow{2}{*}{$\begin{array}{c}\text { Sub } \\
\text { Sub } \\
\text { Variab } \\
\text { el } \\
\end{array}$} & \multirow[b]{2}{*}{$\begin{array}{c}\text { Indika } \\
\text { tor }\end{array}$} & \multicolumn{4}{|c|}{ Nilai } \\
\hline & & & & 1 & 2 & 3 & 4 \\
\hline \multirow[t]{5}{*}{$\begin{array}{l}\text { Pengemb } \\
\text { angan } \\
\text { Mobile } \\
\text { Multime } \\
\text { dia } \\
\text { Learning }\end{array}$} & \multirow[t]{2}{*}{$\begin{array}{l}\text { Eduk } \\
\text { atif }\end{array}$} & \multirow[t]{2}{*}{$\begin{array}{l}\text { Kemam } \\
\text { puan } \\
\text { dalam } \\
\text { membe } \\
\text { rikan } \\
\text { kesemp } \\
\text { atan } \\
\text { belajar }\end{array}$} & $\begin{array}{l}\text { Media } \\
\text { berupa } \\
\text { mobile } \\
\text { multim } \\
\text { edia } \\
\text { learnin } \\
\text { g layak } \\
\text { untuk } \\
\text { dijadik } \\
\text { an } \\
\text { sebagai } \\
\text { sumber } \\
\text { belajar }\end{array}$ & & & & $\sqrt{ }$ \\
\hline & & & $\begin{array}{l}\text { Media } \\
\text { berupa } \\
\text { mobile } \\
\text { multim } \\
\text { edia } \\
\text { learnin } \\
\text { g dapat } \\
\text { kapan } \\
\text { saja } \\
\text { diguna } \\
\text { kan } \\
\text { untuk } \\
\text { belajar }\end{array}$ & & & & $\sqrt{ }$ \\
\hline & \multirow[t]{3}{*}{$\begin{array}{l}\text { Kuali } \\
\text { tas } \\
\text { Tekn } \\
\text { is }\end{array}$} & \multirow[t]{3}{*}{$\begin{array}{l}\text { Kemam } \\
\text { puan } \\
\text { media } \\
\text { dalam } \\
\text { membe } \\
\text { rikan } \\
\text { daya } \\
\text { tarik }\end{array}$} & $\begin{array}{l}\text { Desain } \\
\text { dan } \\
\text { tampila } \\
\mathrm{n} \\
\text { layout } \\
\text { progra } \\
\mathrm{m} \\
\text { sudah } \\
\text { sesuai } \\
\text { dengan } \\
\text { tingkat } \\
\text { jenjang } \\
\text { pebelaj } \\
\text { ar }\end{array}$ & & & & $\sqrt{ }$ \\
\hline & & & $\begin{array}{l}\text { Sub } \\
\text { menu } \\
\text { sudah } \\
\text { sesuai } \\
\text { dengan } \\
\text { isi } \\
\text { menu } \\
\text { yang } \\
\text { disajik } \\
\text { an }\end{array}$ & & & & $\sqrt{ }$ \\
\hline & & & $\begin{array}{l}\text { Anima } \\
\text { si } \\
\text { progra } \\
\text { m } \\
\text { sudah }\end{array}$ & & & & $\sqrt{ }$ \\
\hline
\end{tabular}

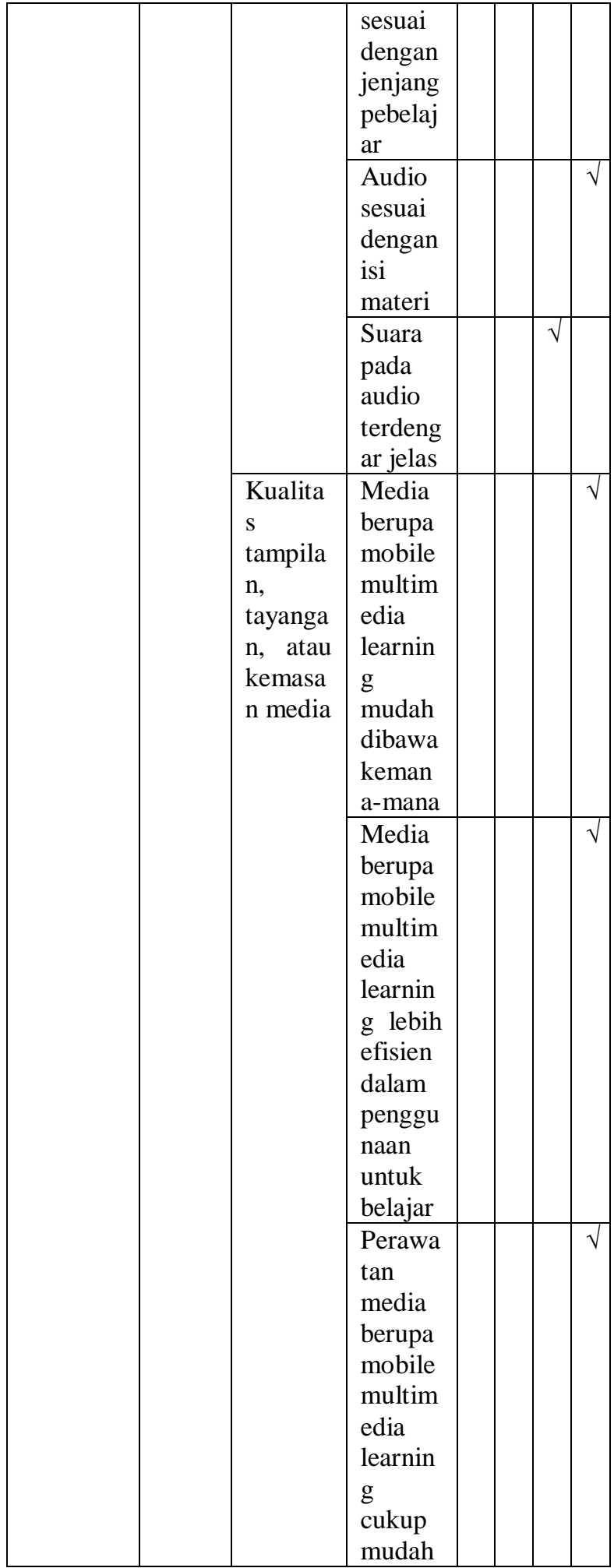

Tabel 8 Penilaian Ahli Media II

\begin{tabular}{|c|c|c|c|c|c|c|c|}
\hline \multirow[b]{2}{*}{ Variabel } & \multirow{2}{*}{$\begin{array}{c}\text { Sub } \\
\text { Varia } \\
\text { bel }\end{array}$} & \multirow{2}{*}{$\begin{array}{c}\text { Sub Sub } \\
\text { Variabe } \\
\text { l }\end{array}$} & \multirow{2}{*}{$\begin{array}{c}\text { Indikat } \\
\text { or }\end{array}$} & \multicolumn{4}{|c|}{ Nilai } \\
\hline & & & & 1 & 2 & 3 & 4 \\
\hline $\begin{array}{l}\text { Pengemba } \\
\text { ngan } \\
\text { Mobile } \\
\text { Multimedi } \\
\text { a Learning }\end{array}$ & $\begin{array}{l}\text { Eduka } \\
\text { tif }\end{array}$ & $\begin{array}{l}\text { Kemamp } \\
\text { uan } \\
\text { dalam } \\
\text { memberi } \\
\text { kan } \\
\text { kesempa }\end{array}$ & $\begin{array}{l}\text { Media } \\
\text { berupa } \\
\text { mobile } \\
\text { multime } \\
\text { dia } \\
\text { learning }\end{array}$ & & & & $\sqrt{ }$ \\
\hline
\end{tabular}




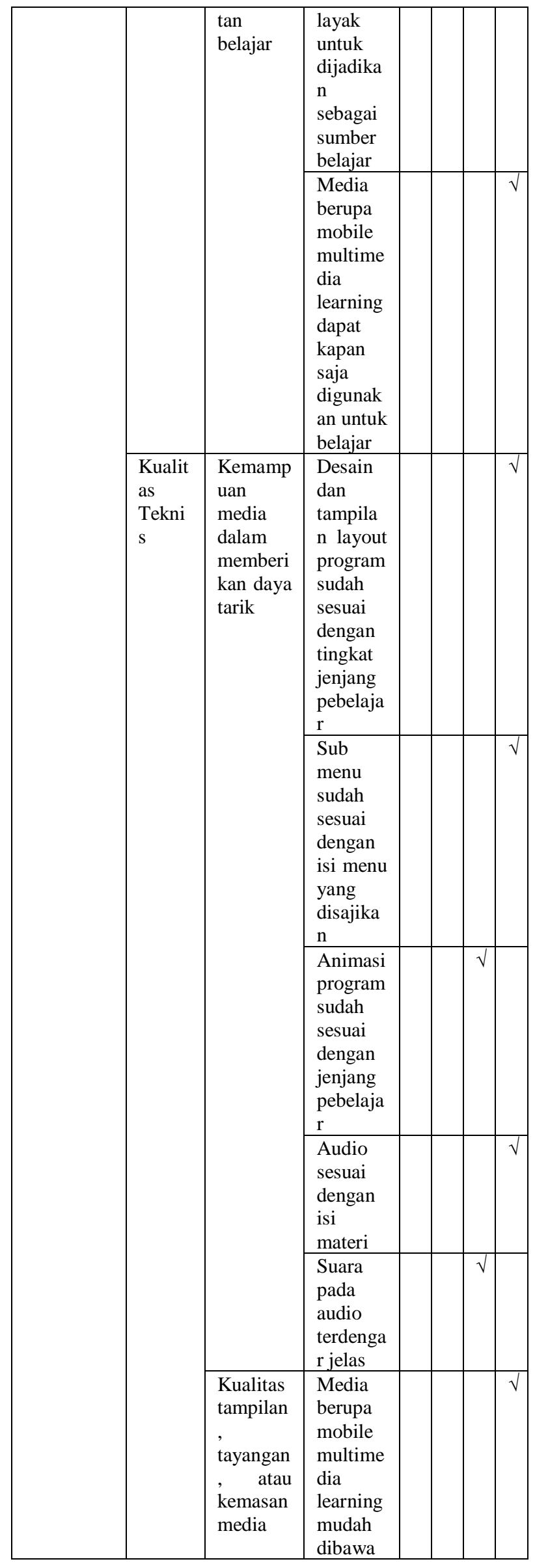

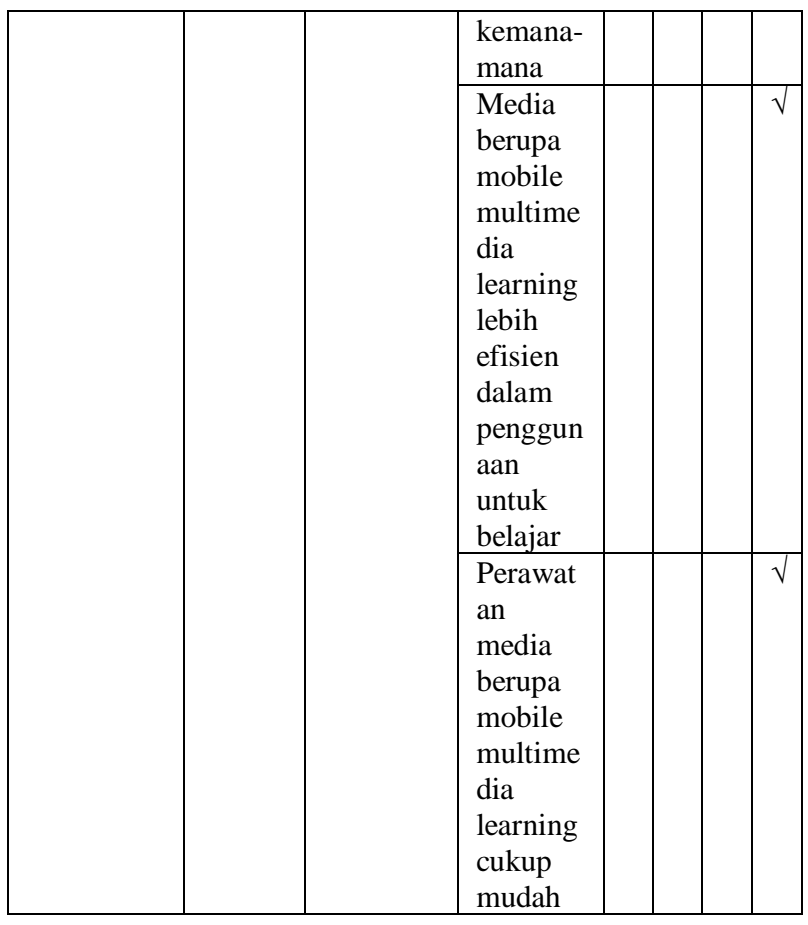

Tabel 9 Penilaian Perhitungan Penilaian Ahli Media Setiap Butir Soal

\begin{tabular}{|c|c|c|}
\hline No. Butir & $\begin{array}{c}\text { Perhitungan Setiap } \\
\text { Aspek }\end{array}$ & Hasil \\
\hline 1 & $\frac{8}{8} \times 100 \%$ & $100 \%$ \\
\hline 2 & $\frac{8}{8} \times 100 \%$ & $100 \%$ \\
\hline 3 & $\frac{8}{8} \times 100 \%$ & $100 \%$ \\
\hline 4 & $\frac{8}{8} \times 100 \%$ & $100 \%$ \\
\hline 5 & $\frac{7}{8} \times 100 \%$ & $87,5 \%$ \\
\hline 6 & $\frac{8}{8} \times 100 \%$ & $100 \%$ \\
\hline 7 & $\frac{6}{8} \times 100 \%$ & $75 \%$ \\
\hline 8 & $\frac{8}{8} \times 100 \%$ & $100 \%$ \\
\hline 9 & $\frac{8}{8} \times 100 \%$ & $100 \%$ \\
\hline 10 & $\frac{8}{8} \times 100 \%$ & $100 \%$ \\
\hline
\end{tabular}

Hasil perhitungan data validasi dengan ahli materi seluruh butir soal sebagai berikut:

(1) Dari segi edukatif

$$
\begin{aligned}
\text { PSA } & \frac{\text { Epenilaian seluruh aspek }}{\text { Epenilaian ideal seluruh aspek }} 100 \% \\
= & \frac{8+8}{16} 100 \% \\
= & \frac{16}{16} 100 \%
\end{aligned}
$$


$=100 \%$

(2) Dari segi kualitas teknis

$$
\begin{aligned}
\text { PSA } & \frac{\text { Dpenilaian seluruh aspek }}{=} 100 \% \\
= & \frac{8+8+7+8+6+8+8+8}{\text { Epenilaian ideal seluruh aspek }} 100 \% \\
= & \frac{61}{64} 100 \% \\
= & 95,31 \%
\end{aligned}
$$

(3) Secara keseluruhan

$$
\begin{aligned}
\text { PSA } & \frac{\text { Epenilaian seluruh aspek }}{\text { Mpenilaian ideal seluruh aspek }} 100 \% \\
= & \frac{8+8+8+8+7+8+6+8+8+8}{72} 100 \% \\
= & \frac{77}{80} 100 \% \\
= & 96,25 \%
\end{aligned}
$$

Berdasarkan hasil analisis data uji coba ahli media tersebut, diperoleh $100 \%$ pada sub variable persoalan segi edukatif dan diperoleh 95,31\% pada sub variable persoalan segi kualitas teknis. Dimana pada Arikunto (2010) jika hasil analisis data didapat $100 \%$ dan 96,25\% termasuk pada kategori sangat baik, maka dapat diambil kesimpulan bahwa media pembelajaran mobile learning materi perkakas tangan layak digunakan dalam hal media pembelajaran.

\section{Evaluasi}

Evaliasi yang pada tahap ini dilakukan, yakni evaluasi yang orientasinya pada

\begin{tabular}{|c|c|}
\hline Sebelum Perbaikan & Sesudah Perbaikan \\
\hline $\begin{array}{c}\text { Cari definisi yang } \\
\text { logis }\end{array}$ & $\begin{array}{l}\text { Semua definisi pada } \\
\text { masing-masing materi } \\
\text { telah diganti dengan } \\
\text { definisi yang lebih } \\
\text { logis }\end{array}$ \\
\hline $\begin{array}{l}\text { Audio materi lebih } \\
\text { spesifik tentang } \\
\text { materi, info lain }\end{array}$ & $\begin{array}{c}\text { Telah dilakukan } \\
\text { perbaikan pada audio, } \\
\text { yakni audio } 1 \\
\text { menjelaskan }\end{array}$ \\
\hline
\end{tabular}
kelayakan multimedia melalui perbaikan-

\begin{tabular}{|c|c|}
\hline $\begin{array}{l}\text { tentang materi, cara } \\
\text { melakukan gerakan }\end{array}$ & $\begin{array}{c}\text { pengertian materi dan } \\
\text { audio } 2 \text { menjeaskan } \\
\text { cara melakukan } \\
\text { gerakan (disertai } \\
\text { gentian konten pada } \\
\text { materi) } \\
\end{array}$ \\
\hline $\begin{array}{l}\text { Animasi kombinasi } \\
\text { setelah berlari dibuat } \\
\text { langsung meloncat }\end{array}$ & $\begin{array}{c}\text { Animasi kombinasi } \\
\text { gerakan telah } \\
\text { diperbaiki, setelah } \\
\text { berlari langsung } \\
\text { meloncat } \\
\end{array}$ \\
\hline $\begin{array}{c}\text { Sebaiknya jangan } \\
\text { menggunakan kata } \\
\text { lantai, gunakan tanah }\end{array}$ & $\begin{array}{l}\text { Sudah mengubah } \\
\text { semua kata "lantai", } \\
\text { menjadi "tanah" }\end{array}$ \\
\hline $\begin{array}{l}\text { Tambahkan petunjuk } \\
\text { sebelum melakukan } \\
\text { kegiatan, saran dan } \\
\text { anjuran memakai } \\
\text { sepatu, memilih } \\
\text { tempat untuk } \\
\text { melakukan semua } \\
\text { kegiatan tersebut. }\end{array}$ & $\begin{array}{l}\text { Sudah ditambahkan } \\
\text { Anjuran pada } \\
\text { prasyarat. Berisikan } \\
\text { anjuran tentang apa } \\
\text { saja persiapan yang } \\
\text { perlu dilakukan } \\
\text { sebelum melakukan } \\
\text { gerak berjalan, berlari } \\
\text { dan meloncat }\end{array}$ \\
\hline $\begin{array}{l}\text { Ini perlu direvisi ya, } \\
\text { pada gerakan berlari } \\
\text { ada saat melayang di } \\
\text { udara shg kaki tdk } \\
\text { menapak ke tanah. }\end{array}$ & $\begin{array}{l}\text { Telah diubah menjadi } \\
\text { "pada gerakan berlari } \\
\text { ada saat melayang di } \\
\text { udara shg kaki tdk } \\
\text { menapak ke tanah" }\end{array}$ \\
\hline $\begin{array}{l}\text { Jika untuk sekolahan } \\
\text { gunakan Guru PJOK }\end{array}$ & $\begin{array}{l}\text { Telah menggunakan } \\
\text { guru PJOK pada } \\
\text { anjuran halaman } \\
\text { terakhir }\end{array}$ \\
\hline $\begin{array}{c}\text { Yang Benar Gerakan } \\
\text { Kombinasi }\end{array}$ & $\begin{array}{l}\text { Telah diganti menjadi } \\
\text { Gerakan Kombinasi }\end{array}$ \\
\hline $\begin{array}{l}\text { Beri keterangan utk } \\
\text { tangannya bgmn saat } \\
\text { berlari }\end{array}$ & $\begin{array}{c}\text { Telah diberikan } \\
\text { keterangan untuk } \\
\text { tangan bagaimana saat } \\
\text { berlari }\end{array}$ \\
\hline $\begin{array}{c}\text { Beri keterangan utk } \\
\text { tangannya bgmn saat } \\
\text { Meloncat }\end{array}$ & $\begin{array}{c}\text { Telah diberikan } \\
\text { keterangan untuk } \\
\text { tangan bagaimana saat } \\
\text { meloncat }\end{array}$ \\
\hline
\end{tabular}
perbaikan yang dilakukan terhadap penilaian ahli materi serta ahli media.

Sebelum media dilakukan penilaian kelayakan oleh ahli materi dan ahli media, terdapat beberapa perbaikan hingga media benar-benar dinilai dan dilakukan penilaian kelayakan.

\section{Tabel 10 Perbaikan Ahli Materi 1}

\section{Tabel 11 Perbaikan Ahli Materi 1I}

\begin{tabular}{|c|c|}
\hline Sebelum Perbaikan & Sesudah Perbaikan \\
\hline $\begin{array}{c}\text { Semoga aplikasi ini } \\
\text { dapat dikembangkan } \\
\text { pada semua materi } \\
\text { PJOK yang berkaitan } \\
\text { dengan aktifitas gerak } \\
\text { siswa SD }\end{array}$ & $\begin{array}{c}\text { Telah direvisi menjadi } \\
\text { dapat dikembangkan } \\
\text { pada semua materi } \\
\text { PJOK yang berkaitan } \\
\text { dengan aktifitas gerak } \\
\text { siswa SD" }\end{array}$ \\
\hline Tidak perlu (:) & Tanda (:) telah \\
& dihilangkan \\
\hline Lebih diperjalas & Telah diperjelas, teori \\
pengertian dari & yang dimaksudkan \\
melompat. Cari & dalam aplikasi \\
sumber terkait & mengarah ke \\
\hline
\end{tabular}




\begin{tabular}{|c|c|}
\hline $\begin{array}{c}\text { perbedaan melompat } \\
\text { dengan meloncat }\end{array}$ & $\begin{array}{c}\text { pengertian dari } \\
\text { meloncat }\end{array}$ \\
\hline $\begin{array}{l}\text { Kalimat masih bias. } \\
\text { Lebih di perjelas } \\
\text { maksud dantujuannya. }\end{array}$ & $\begin{array}{l}\text { Tujuan dari section ini } \\
\text { sudah diperjelas. } \\
\text { Untuk melakukan } \\
\text { ketiga gerakan dasar } \\
\text { lokomotor (berjalan, } \\
\text { berlari, dan meloncat) }\end{array}$ \\
\hline $\begin{array}{l}\text { Berikan penjelasan } \\
\text { sesuai sumber terkait } \\
\text { apa itu melompat dan } \\
\text { meloncat? Intinya } \\
\text { sesuaikan dengan } \\
\text { gerakan pada gambar. } \\
\text { Tumpuan } 2 \text { kaki dan } \\
\text { mendarat dengan } 2 \\
\text { kaki itu merupakan } \\
\text { melompat atau } \\
\text { meloncat? }\end{array}$ & $\begin{array}{l}\text { Telah diperbaiki, } \\
\text { sesuai dengan materi } \\
\text { yang dimaksudkan, } \\
\text { teori mengarah ke } \\
\text { gerak meloncat. }\end{array}$ \\
\hline $\begin{array}{l}\text { Pada gambar yg } \\
\text { bergerak, berlari lnya } \\
\text { tdk nampak berlari } \\
\text { tetapi berjalan. }\end{array}$ & $\begin{array}{c}\text { Bug ada animasi gerak } \\
\text { berlari tampak atas } \\
\text { sudah diperbaiki. } \\
\text { Frame persecond } \\
\text { sudah disamakan. }\end{array}$ \\
\hline $\begin{array}{l}\text { Tidak perlu diberikan } \\
\text { pengantar, langsung } \\
\text { pada pengertian berlari } \\
\text { saja. }\end{array}$ & $\begin{array}{l}\text { Telah diubah langsung } \\
\text { pada pengertian } \\
\text { berlari. }\end{array}$ \\
\hline $\begin{array}{l}\text { Fungsi pada petunjuk } \\
\text { kurang (s) }\end{array}$ & $\begin{array}{l}\text { Telah ditambahkan } \\
\text { huruf (s) pada kata } \\
\text { Fungsi }\end{array}$ \\
\hline $\begin{array}{l}\text { Aplikasi pada petunjuk } \\
\text { kurang (L) }\end{array}$ & $\begin{array}{c}\text { Telah ditambahkan } \\
\text { huruf (l) pada kata } \\
\text { Aplikasi }\end{array}$ \\
\hline $\begin{array}{l}\text { Penggunaan pada } \\
\text { petunjuk kurang }(\mathrm{g})\end{array}$ & $\begin{array}{l}\text { Telah ditambahkan } \\
\text { huruf }(\mathrm{g}) \text { pada kata } \\
\text { Penggunaan }\end{array}$ \\
\hline
\end{tabular}

\section{Tabel 11 Perbaikan Ahli Media II}

\begin{tabular}{|c|c|}
\hline $\begin{array}{c}\text { Sebelum } \\
\text { Perbaikan }\end{array}$ & $\begin{array}{c}\text { Sesudah } \\
\text { Perbaikan }\end{array}$ \\
\hline $\begin{array}{c}\text { Ubah semua warna } \\
\text { font pada isi } \\
\text { konten menjadi } \\
\text { hitam }\end{array}$ & $\begin{array}{c}\text { Warna font pada } \\
\text { isi konten telah } \\
\text { diubah menjadi } \\
\text { hitam }\end{array}$ \\
\hline
\end{tabular}

\section{KESIMPULAN}

Berdasarkan proses pengembangan dan hasil uji coba terhadap mobile multimedia learning mata pelajaran pendidikan jasmani olahraga dan kesehatan materi kombinasi gerak berjalan berlari dan meloncat untuk siswa kelas III di Sekolah Dasar Insan Mulya Driyorejo Kabupten Gresik sebagai berikut: Model pengembangan yang digunakan adalah model pengembangan multimedia Lee \&
Owens yang terdiri dari 5 tahapan, yaitu (1)

Penilaian/analisis, (2) Desain,

Pengembangan, (4) Implementasi, dan (5) Evaluasi. Kelayakan produk media pembelajaran yang dikembangkan berdasar dari hasil validasi uji ahli materi dan uji validasi ahli media.

Berdasarkan hasil analisis data uji coba ahli materi, diperoleh $93,1 \%$ pada sub variable persoalan segi isi materi dan hasil uji ahli media diperoleh $100 \%$ pada sub variable persoalan segi edukatif dan diperoleh $95,31 \%$ pada sub variable persoalan segi kualitas teknis. Dimana pada Arikunto (2010) jika hasil analisis data didapat $100 \%$ dan $96,25 \%$ termasuk pada kategori sangat baik., sehingga media layak digunakan untuk siswa kelas III pada mata pelajaran Pendidikan Jasmani Olahraga dan Kesehatan materi kombinasi berjalan berlari dan meloncat di Sekolah Dasar Insan Mulya Driyorejo Kabupaten Gresik.

\section{DAFTAR PUSTAKA}

Arikunto, Suharsimi. 2013. Prosedur Penelitian Suatu Pendekatan Praktik. Jakarta: CV. Rajawali.

Binanto, Iwan. 2010. Multimedia Digital Dasar Teori dan Pengembangannya. Yogyakarta: Andi.

Dwi, Herman, Surjono. 2017. Multimedia Pembelajaran Interaktif Konsep dan Pengembangan Edisi Pertama. Yogyakarta: UNY Press.

Hofstetter, Fred T. 2001. Multimedia Literacy Third Edition. New York: McG raw Hill International Edition.

Januzewsky, Alan, Michael Molenda. 2008. Educational Technology: A Definition With Comentary. New Jersey: Lawrence Erlbaum Associates.

Lee, W.W., \& Owens, D.L. 2004. Multimediabased Instructional Design: Computer-based Training, Webbased Training, Distance Broadcast Training, Performance-based Solutions. San Fransisco: Pfeiffer. 
Mayer, R. E. 2009. Multimedia learning 2nd Edition. Cambridge: Cambridge University Press.

Munir. 2009. Kurikulum Berbasis Teknologi Informasi dan Komunikasi. Bandung: Alfabeta.

Munir. 2012. Multimedia Konsep \& Aplikasi dalam Pendidikan. Bandung: Alfabeta.

Nesbit, J.C., Berfer, K. \& Vargo, J. 2002. “ $A$ Convergent Participant Model for Evaluation of Learning Objects" dalam Canadian Journal of Learning and Technology. 28(3): 105-120.

Rahmayani, Indah. 2015. Indonesia Raksasa Teknologi Digital Asia, diakses 23 Oktober 2020 dari https://www.kominfo.go.id/content/d etail/6095/indonesia-raksasateknologi-digitalasia/0/sorotan_media.

Safie A'fza, Norshahila Ibrahim. 2015. "Multimedia Mobile Learning Application for Children's Education: The Development of MFolktales" dalam Journal Canadian Center of Science and Education. Vol. 11, No. 24

Sugiyono. 2010. Metode Penelitian Kuantitatif dan Kualitatif dan $R \& D$. Bandung: Alfabeta.

Sukiyandari, L., Soegiyanto., \& Rustiana, E. R. 2015. "Multimedia Bola Basket untuk Pembelajaran Pendidikan Jasmani Olahraga dan Kesehatan Disma" dalam Journal of Phisical Education and Sports, 4(2), 122-128.

Thobroni. 2016. Belajar dan Pembelajaran Teori dan Praktek. Jakarta: ARRUZZ MEDIA.

Trentin, Guglielmo. 2013 Using Network and Mobile Tchnology to Brigde Formal and Informal Learning. Cambridge: Candos Publishing Limited

Wiradiharja, Sudrajat., Syarifudin. 2017. Pendidikan Jasmani Olahraga Dan Kesehatan. Jakarta: Kementrian Pendidikan dan Kebudayaan 